\title{
Benthic dinoflagellates in Korean waters
}

\author{
An Suk Lim ${ }^{1}$ and Hae Jin Jeong ${ }^{2,3, *}$ \\ ${ }^{1}$ Division of Life Science \& Plant Molecular Biology and Biotechnology Research Center, Gyeongsang National University, \\ Jinju 52828, Korea \\ ${ }^{2}$ School of Earth and Environmental Sciences, College of Natural Sciences, Seoul National University, Seoul 08826, Korea \\ ${ }^{3}$ Research Institute of Oceanography, Seoul National University, Seoul 08826, Korea
}

The occurrence of benthic dinoflagellates, many of which are known to be toxic, is a critical concern for scientists, government officers, and people in the aquaculture, dining, and tourism industries. The interest in these dinoflagellates in countries with temperate climate is increasing because tropical or subtropical species introduced into temperate waters by currents are able to survive the winter season in the new environment owing to global warming. Recently, several species from the benthic dinoflagellate genera Amphidinium, Coolia, Ostreopsis, Gambierdiscus, and Prorocentrum have been reported in the waters of the South and East Sea of Korea. The advent of the benthic dinoflagellates in Korean waters is especially important because raw or slightly cooked seaweeds, which may harbor these benthic dinoflagellates, as well as raw fish, which can be potentially intoxicated by phytotoxins produced by some of these benthic dinoflagellates, are part of the daily Korean diet. The recent increase in temperature of Korean coastal waters has allowed for the expansion of benthic dinoflagellate species into these regions. In the present study, we reviewed the species, distribution, and toxicity of the benthic dinoflagellates that have been reported in Korean waters. We also provided an insight into the ecological and socio-economic importance of the occurrence of benthic dinoflagellates in Korean waters.

Key Words: Amphidinium; Coolia; epiphytic; Gambierdiscus; Ostreopsis; Prorocentrum; warming

\section{INTRODUCTION}

Dinoflagellates are a major component of marine ecosystems (Lessard 1991, Jeong 1999, Sherr and Sherr 2007, Terrado et al. 2009, Jeong et al. 2021b). They live in diverse environments and play diverse roles in marine food webs (reviewed by Jeong et al. 2010). Although the majority of dinoflagellates are planktonic and often form blooms in the water column (Jeong et al. 2015, 2021a), many dinoflagellate species are benthic (Tindall and Morton 1998, Kim et al. 2011). Some benthic dinoflagellates contain toxins, such as palytoxin, ciguatoxin, maitotoxin, gambierol, okadaic acid, cooliatoxin, and prorocentrolides (Litaker et al. 2010, Holmes et al. 2014, Tester et al. 2020).
Therefore, the occurrence of benthic dinoflagellates is a critical concern for scientists, government officers, and people in the aquaculture, dining, and tourism industries. Many benthic dinoflagellate species are distributed in tropical or subtropical waters, and fewer species occur in temperate waters (Besada et al. 1982, Tindall and Morton 1998, Zingone et al. 2006, Fraga et al. 2008, Hallegraeff 2010, Leaw et al. 2010, Glibert et al. 2012, Parsons et al. 2012, Larsson et al. 2019, Pavaux et al. 2020, Tester et al. 2020). However, the distribution of some benthic dinoflagellates living in tropic or subtropic waters has expanded into temperate waters owing to the elevated waterms of the Creative Commons Attribution Non-Commercial License (http://creativecommons.org/licenses/by-nc/3.0/) which permits unrestricted non-commercial use, distribution, and reproduction in any medium, provided the original work is properly cited.
Received April 7, 2021, Accepted May 31, 2021

* Corresponding Author

E-mail: hjjeong@snu.ac.kr

Tel: +82-2-880-6746, Fax: +82-2-874-9695 
ter temperatures driven by global warming (e.g., Shears and Ross 2009, Jeong et al. 2012a, 2012b).

In the last decade, several benthic dinoflagellate species have been reported from Korean waters (Kim et al. 2011, Baek 2012a, 2012b, Jeong et al. 2012a, 2012b, Kang et al. 2013, Lee et al. 2013, Lim et al. 2013, Shah et al. 2013a, 2013b, 2014a, 2014b, Jang et al. 2018, Kim and Seo 2019, Lee and Park 2020, Park et al. 2020). Most of these reported species have been found in the coastal waters of Jeju Island, which is located at the south end of Korea $\left(33.5^{\circ} \mathrm{N}\right.$ in latitude), but some species have been found in the South Sea and East Sea of Korea $\left(\sim 38.0^{\circ} \mathrm{N}\right)$. The toxins of some benthic dinoflagellates are known to cause illness in humans who consume seafood contaminated by the toxins bioaccumulated through food webs or when directly exposed to seawater and / or aerosol during benthic dinoflagellate blooms (Tichadou et al. 2010, Tubaro et al. 2011, Ciminiello et al. 2014, Accoroni and Totti 2016,
Pavaux et al. 2020, Tester et al. 2020). Many Koreans readily consume raw or slightly cooked macroalgae and fish. Therefore, the distribution of these benthic dinoflagellates and the presence of toxins in Korean waters are of critical concern.

The surface water temperature around Korea has been gradually increasing (Han and Lee 2020). This may allow some invasive subtropical species transported via currents or ballast waters to survive over the winter in Korea. Tropical cyclones (e.g., typhoons) occur annually in Korea (http:// www.weather.go.kr). Strong water movements during these events may detach benthic dinoflagellates from the thalli of macroalgae (Tindall and Morton 1998, Cruz-Rivera and Villareal 2006) in Jeju waters or the South Sea and transport them to the eastern and western coasts of Korea.

In the present study, we reviewed the species, distribution, and toxicity of benthic dinoflagellates in Korean wa-

Table 1. The benthic dinoflagellates reported from Korean waters, their GenBank accession numbers, and the location, water temperature ( $\mathrm{T}$ ), and salinity (S) where the dinoflagellates were isolated or found

\begin{tabular}{|c|c|c|c|c|c|}
\hline Species & Location & $\mathrm{T}\left({ }^{\circ} \mathrm{C}\right)$ & $S$ & GenBank accession No. & Reference \\
\hline Coolia canariensis & Jeju Island & 14.8 & 33.7 & FR846193-5, FR847223-4 & Jeong et al. $(2012 b)$ \\
\hline C. malayensis & Jeju Island & $20.5-21.1$ & $32.3-28.6$ & FR848949-50, FR847217-22 & Jeong et al. $(2012 b)$ \\
\hline C. malayensis & Jeju Island & $10.9-26.3$ & $23.6-34.8$ & - & Shah et al. $(2013 a, 2013 b)$ \\
\hline Coolia spp. & Jeju Island, East coast & $21.0-23.6$ & $28.9-32.5$ & - & $\begin{array}{l}\text { Kim et al. (2011), Baek } \\
(2012 a)\end{array}$ \\
\hline Gambierdiscus toxicus & Jeju Island & NA & NA & - & Baek $(2012 b)$ \\
\hline $\begin{array}{l}\text { G. jejuensis (previously } \\
\text { reported as G. caribaeus) }\end{array}$ & Jeju Island & 14.4 & $33.1-33.8$ & $\begin{array}{l}\text { HE775087, MH827555- } \\
\text { MH827562 }\end{array}$ & $\begin{array}{l}\text { Jeong et al. (2012a), Jang } \\
\text { et al. (2018) }\end{array}$ \\
\hline G. yasumotoi & Jeju Island & NA & NA & - & Shah et al. $(2013 a, 2014 a)$ \\
\hline Gambierdiscus spp. & $\begin{array}{l}\text { Baek and Jeju Islands, } \\
\text { East and South coast }\end{array}$ & $13-23.6$ & $28.9-34$ & - & $\begin{array}{l}\text { Kim et al. (2011), Baek } \\
(2012 b)\end{array}$ \\
\hline Ostreopsis ovata & Jeju Island & $10.9-26.3$ & $23.6-34.8$ & - & Shah et al. $(2013 a, 2013 b)$ \\
\hline O. cf. ovata & Jeju Island & 18.6 & 31.2 & HE793379 & Kang et al. (2013) \\
\hline Ostreopsis sp. 1 & Jeju Island & $15.8-18.3$ & $33.4-34.8$ & MK558223-8 & Kim and Seo (2019) \\
\hline Ostreopsis sp. 6 & Jeju Island & $25.0-30.0$ & $32.0-33.0$ & NA & Lee and Park (2020) \\
\hline Ostreopsis spp. & $\begin{array}{l}\text { Jeju and Chuja Islands, } \\
\text { South and East coasts }\end{array}$ & $18.6-29.5$ & $28.9-35.0$ & - & $\begin{array}{l}\text { Kim et al. (2011), Baek } \\
\text { (2012a), Lee and Park } \\
(2018)\end{array}$ \\
\hline Amphidinium carterae & Jeju Island & $10.9-26.3$ & $23.6-34.8$ & - & Shah et al. $(2013 a, 2013 b)$ \\
\hline A. massartii & Jeju Island & 22.7 & 33.7 & HF674441-674443 & Lee et al. (2013) \\
\hline A. operculatum & Jeju Island & $10.9-26.3$ & $23.6-34.8$ & - & Shah et al. $(2013 a, 2013 b)$ \\
\hline Amphidinium spp. & $\begin{array}{l}\text { Jeju Island, East and } \\
\text { South coasts }\end{array}$ & $21.0-23.6$ & $28.9-32.5$ & - & $\begin{array}{l}\text { Kim et al. (2011), Baek } \\
\text { (2012a) }\end{array}$ \\
\hline Prorocentrum concavum & Jeju Island & $10.9-26.3$ & $23.6-34.8$ & - & Shah et al. $(2013 a, 2013 b)$ \\
\hline P. emarginatum & Jeju Island & $10.9-26.3$ & $23.6-34.8$ & - & Shah et al. $(2013 a, 2013 b)$ \\
\hline P. fukuyoi & Jeju Island & $10.9-26.3$ & $23.6-34.8$ & - & Shah et al. $(2013 a, 2013 b)$ \\
\hline P. lima & Jeju Island & $10.9-26.3$ & $23.6-34.8$ & - & Shah et al. $(2013 a, 2013 b)$ \\
\hline $\begin{array}{l}\text { P. mexicanum (previously } \\
\text { as } P \text { cf. rhathymum) }\end{array}$ & Jeju Island & $14.4-20.5$ & $33.3-33.8$ & HF565181-3 & Lim et al. (2013) \\
\hline $\begin{array}{l}\text { P. mexicanum (previously } \\
\text { as P. rhathymum) }\end{array}$ & Jeju Island & $10.9-26.3$ & $23.6-34.8$ & - & Shah et al. $(2013 a, 2013 b)$ \\
\hline Prorocentrum spp. & $\begin{array}{l}\text { Jeju Island, South and } \\
\text { East coast }\end{array}$ & $21.0-23.6$ & $28.9-32.5$ & - & $\begin{array}{l}\text { Kim et al. (2011), Baek } \\
(2012 a)\end{array}$ \\
\hline
\end{tabular}

NA, not available. 

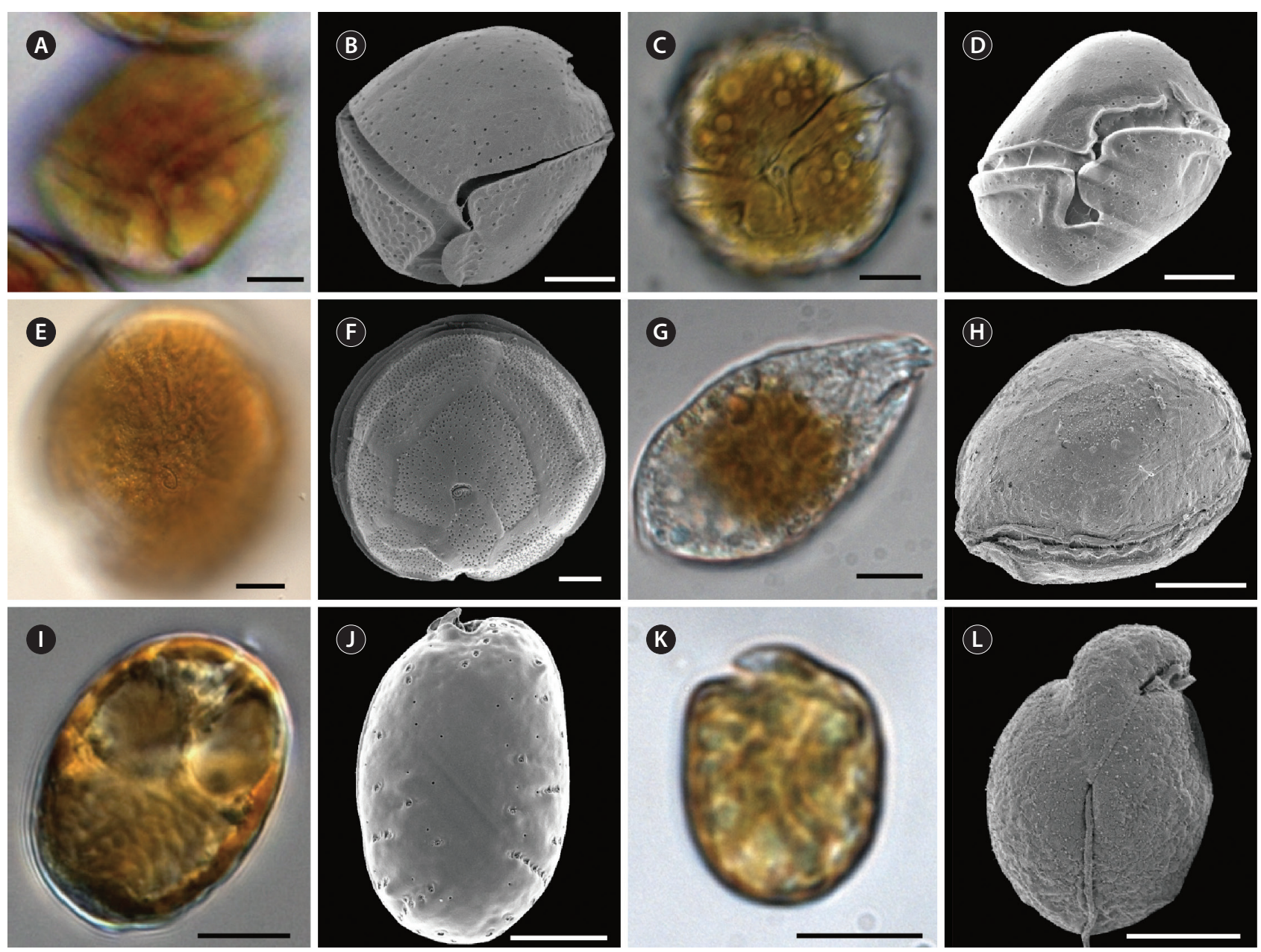

Fig. 1. Micrographs of epibenthic dinoflagellates found in Korean waters. (A \& B) Coolia canariensis CCJJ1. (C \& D) Coolia malayensis CMJJ1. (E \& F) Gambierdiscus jejuensis GCJJ1. (G \& H) Ostreopsis cf. ovata OVJJ1. (I \& J) Prorocentrum mexicanum PRJJ1. (K \& L) Amphidinium massartii AMJJ1. Micrographs in $A, C, E, G, I$, and $K$ were taken using a light microscope, while those in $B, D, F, H$, J, and $L$ were taken using a scanning electron microscope. Scale bars represent: $A-L, 10 \mu \mathrm{m}$.

ters, and also provided an insight into the ecological and socio-economic importance of the occurrence of benthic dinoflagellates in Korean waters.

\section{TAXONOMIC COMPOSITION AND MORPHO- LOGICAL AND GENETIC CHARACTERIZATIONS OF BENTHIC DINOFLAGELLATES IN KOREAN WATERS}

Kim et al. (2011) were the first to report the presence of benthic dinoflagellates in Korean waters; they found five benthic dinoflagellate genera, Amphidinium, Coolia, Gambierdiscus, Ostreopsis, and Prorocentrum, in the coastal waters of Jeju Island in the fall of 2009 (Table 1). In their study, the dinoflagellates were identified to the genus level based on morphological characteristics observed under a light microscope. Later, several benthic dinoflagellate species isolated in the coastal waters of Jeju Island and cultured in the laboratory were identified using both morphological and genetic analyses (Jeong et al. 2012a, 2012b, Kang et al. 2013, Lee et al. 2013, Lim et al. 2013, Jang et al. 2018) (Fig. 1). Subsequently, several studies reported the presence of diverse benthic dinoflagellate species in Jeju waters and the South and East Sea of Korea (Table 1). However, the identification of some of those species was conducted only by morphological analysis under a light microscope.

In general, the overall shapes of the Korean strains of Coolia canariensis, C. malayensis, and Ostreopsis spp. were similar to those of previously reported strains isolated from the waters of other countries, but the molecular 
characterizations of the Korean strains were somewhat different from those of the previously described strains (Jeong et al. 2012a, 2012b, Kang et al. 2013, Kim and Seo 2019). The benthic dinoflagellate Gambierdiscus jejuensis isolated from the waters off Jeju Island was recently described as a new species (Jang et al. 2018). Detailed morphological and molecular characterizations of the Korean strains are provided below.

\section{Coolia spp.}

Two Coolia species, C. canariensis and C. malayensis, have been reported in Korean waters (Jeong et al. 2012b). These species were found in the waters off Jeju Island and were identified using both morphological and genetic analyses. The morphologies of the Korean strains of C. canariensis CCJJ1 and C. malayensis CMJJ1 and CMJJ2 were similar to those of the original Canary Islands and Malaysian strains, respectively (Fraga et al. 2008, Leaw et al. 2010, Jeong et al. 2012b). Using scanning electron micrography (SEM), Jeong et al. (2012b) reported the exact number and shape of the sulcal plates of Korean strains of C. canariensis and C. malayensis, and reported the complete Kofoidian plate formulae as Po, $3^{\prime}, 7^{\prime \prime}, 6 \mathrm{c}$, 6s, 5"', and 2"'"' for C. canariensis and Po, 3', 7", 7c, 6-7s, $5^{\prime \prime \prime}$, and $2^{\prime \prime \prime \prime}$ for C. malayensis. Moreover, these authors were the first to report the number of pores in the apical pore complex and a line of small knobs on the pore plates of C. canariensis and C. malayensis. Jeong et al. (2012b) also observed perforations within the large pores of the Korean strains of C. canariensis and C. malayensis. Perforations have been found previously in the Malaysian strains of C. malayensis (Leaw et al. 2010), and thus Jeong et al. (2012b) suggested that the perforations are a common feature of Coolia species.

Jeong et al. (2012b) reported that the large subunit (LSU) rDNA sequence of the Korean strain C. canariensis CCJJ1 is identical to that of the Biscayan strains, but $2-3 \%$ different from that of the Canary Islands strain VGO0775 and the Australian strain. Additionally, the sequences of the small subunit (SSU) and LSU rDNA from the two Korean strains C. malayensis CMJJ1 and CMJJ2 are $<1 \%$ different from the Malaysian strains of C. malayensis, the Florida strain CCMP1345, and the New Zealand strain CAWD39 (Coolia monotis) (Jeong et al. 2012b). In phylogenetic trees based on LSU rDNA sequences, the Korean strains of $C$. malayensis were placed in a clade with the other strains of the same species. Jeong et al. (2012b) therefore suggested that the Korean strain of C. canariensis was closely related to the two Atlantic strains and the
Australian strain, whereas the Korean strains of C. malayensis were related to the two Malaysian strains and the Florida and New Zealand strains of $C$. malayensis.

\section{Gambierdiscus spp.}

To date, three Gambierdiscus species, G. jejuensis (previously reported as G. caribaeus in Jeong et al. 2012a), G. toxicus, and G. yasumotoi, have been reported in Korean waters (Baek 2012b, Jeong et al. 2012a, Shah et al. 2013a, 2014a, Jang et al. 2018). The Korean strains G. jejuensis GJ1703a and GCJJ1 isolated from the waters off Jeju Island were identified using both morphological and genetic analyses (Jeong et al. 2012a, Jang et al. 2018). Cells of G. toxicus and G. yasumotoi were also found in the South Sea of Korea (Baek 2012b, Shah et al. 2013a, 2014a). However, the molecular characterization of G. toxicus and G. yasumoto i is required to confirm the identification of these species.

The overall morphology of the Korean strains of G. jejuensis (GJ1703a and GCJJ1) isolated from the waters off Jeju Island are similar to that of the original Belize strains of G. caribaeus (Litaker et al. 2009, Jeong et al. 2012a, Jang et al. 2018). The depth, length, and width of living Korean G. jejuensis cells are comparable with those of $G$. caribaeus, whereas some morphological features, such as the length to width ratio of the Po plate and $1 p$ plate, are different from those of G. caribaeus. The sequence of the SSU rDNA and those of the D1-D3 and D8-D10 regions of the LSU rDNA of the Korean G. jejuensis GJ1703a are 2.4-6.1\% different from those of G. caribaeus (Jang et al. 2018). In the phylogenetic trees based on SSU and LSU rDNA sequences, the Korean strains of G. jejuensis formed a clade with strains of Gambierdiscus sp. type 2 isolated from the temperate waters of Korea and Japan. Therefore, Jang et al. (2018) proposed that the Korean strains of $G$. jejuensis and Gambierdiscus sp. type 2 should be classified as new species in the genus Gambierdiscus.

\section{Ostreopsis spp.}

Kim et al. (2011) reported the presence of some Ostreopsis spp. in the coastal waters of Jeju Island, and since then several other Ostreopsis spp. have been found (Table 1) (Kang et al. 2013, Shah et al. 2013a, 2013b, Kim and Seo 2019, Lee and Park 2020). The first Ostreopsis species described in detail using molecular analysis and SEM observations was Ostreopsis cf. ovata (Kang et al. 2013). The overall cell shape and plate formula of the Korean strain $O$. cf. ovata OVJJ1 are similar to those of O. ovata and $O$. 
cf. ovata found in the waters of other countries. Moreover, the D8-D10 sequences of the LSU of the Korean O. cf. ovata OVJJ1 are $0-2.6 \%$ different from those of the Japanese strains of Ostreopsis sp. (Kang et al. 2013). The Korean $O$. cf. ovata OVJJ1 formed a distinct clade together with the Japanese strains of Ostreopsis sp. in the "Ostreopsis sp. 1" clade, which is one of the subclades in the O. ovata species complex (Sato et al. 2011, Kang et al. 2013, Kim and Seo 2019, Lee and Park 2020). Although the D8-D10 sequences of the LSU rDNA of Ostreopsis species in the $O$. ovata species complex show three separate genotypes, $O$. cf. ovata, Ostreopsis sp. 1, and Ostreopsis sp. 2 (Sato et al. 2011), whether the three clades represent distinct species remains uncertain (Parsons et al. 2012, Pavaux et al. 2020, Tester et al. 2020). According to Kang et al. (2013), the cell size, length of the $1 \mathrm{p}$ plate, and cingulum displacement of O. cf. ovata OVJJ1 are different from those of O. cf. ovata strains found in the waters of other countries (Kang et al. 2013). Therefore, if unique morphological traits, other than the aforementioned morphological characters, are discovered for Ostreopsis sp. 1 in future studies, the Korean $O$. cf. ovata OVJJ1 and the strains in the "Ostreopsis sp. 1" clade can be designated as a new species in the genus Ostreopsis.

In addition to the $O$. cf. ovata / Ostreopsis sp. 1 strains, the Ostreopsis sp. $617 \mathrm{JJ} 0908$ strain was recently reported from the waters off Jeju Island (Lee and Park 2020). The 19 isolates including the 17JJ0908 strain formed a distinct "Ostreopsis sp. 6" clade along with other strains from Japan that have been suggested to constitute a new species (Sato et al. 2011, Lee and Park 2020). Some morphological characteristics of the Korean Ostreopsis sp. 6 17JJ0908, such as the uniform size of the thecal pores and a body undulation of the cingulum, are similar to those of $\mathrm{Os}$ treopsis siamensis (Schmidt 1901, Fukuyo 1981, Lee and Park 2020). However, the cell size and the shape in the lateral view of the Korean strain of Ostreopsis sp. 6 17JJ0908 are different from those of O. siamensis (Schmidt 1901, Fukuyo 1981, Lee and Park 2020). Therefore, further studies are needed to test whether the Korean strain of Ostreopsis sp. 6 is O. siamensis.

\section{Amphidinium spp.}

Kim et al. (2011) were the first to report the presence of Amphidinium spp. in the coastal waters of Jeju Island. Later, detailed morphological and molecular characteristics of Amphidinium massartii were revealed through SEM and phylogenetic analyses (Lee et al. 2013). The morphology of the Korean strain A. massartii AMJJ1, such as its overall shape and body scales, coincides with that of an A. massartii strain isolated from Australia (Murray et al. 2012, Lee et al. 2013). Moreover, the sequences of 5.8S, ITS2, and cytochrome $b$ of Korean A. massartii strains (AMJJ1, AMJJ2, and AMJJ3) were identical with those of the Australian A. massartii CS-259 (Lee et al. 2013). Recent phylogenetic and toxicity analyses conducted by Karafas et al. (2017) suggested that the strains in the nontoxic $A$. massartii clade 1 and the toxic $A$. cf. massartii clade 2, which includes the Korean strains of $A$. massartii, may be two distinct species. Nonetheless, the separation of clades 1 and 2 as two species has not been supported by unique morphological characteristics, and the status of the Korean strains of $A$. massartii remains unchanged.

Two benthic Amphidinium species, A. carterae and A. operculatum, have been reported in the waters off Jeju Island (Shah et al. 2013a, 2013b). Their morphological characteristics were examined only under a light microscope, and further taxonomical studies based on morphological and molecular characteristics are required for these Amphidinium spp.

\section{Prorocentrum spp.}

Some benthic Prorocentrum species such as P. concavum, P. emarginatum, P. fukuyoi, P. lima, and P. mexicanum (previously reported as $P$. rhathymum or $P$. cf. rhathymum in Lim et al. 2013, Shah et al. 2013a, 2013b) have been reported in the coastal waters of Jeju Island (Table 1). Except for P. mexicanum PRJJ1, morphological characteristics of these species have been examined only under a light microscope, while the molecular characterizations of most species are lacking.

Some morphological characteristics of the Korean strain of P. mexicanum PRJJ1, such as the oval-shaped cell with a smooth cell surface, a simple collar-shaped spine, and the pattern of the pores on the valves, are similar to those of the original P. rhathymum isolated from the Virgin Islands (Loeblich et al. 1979, Lim et al. 2013). In contrast, the LSU rDNA sequences of the Korean $P$. cf. rhathymum strains (PRJJ1, PRJJ2, and PRJJ3) are similar to those of both P. rhathymum and P. mexicanum; the Korean strains of $P$. cf. rhathymum also formed a clade with both $P$. rhathymum and P. mexicanum strains from different countries (Lim et al. 2013). Recently, P. rhathymum has been revealed as a junior synonym of $P$. mexicanum based on morphological and molecular analyses (Gómez et al. 2017). Therefore, at least five benthic Prorocentrum species, including P. mexicanum, have been reported from the Korean waters so far. 


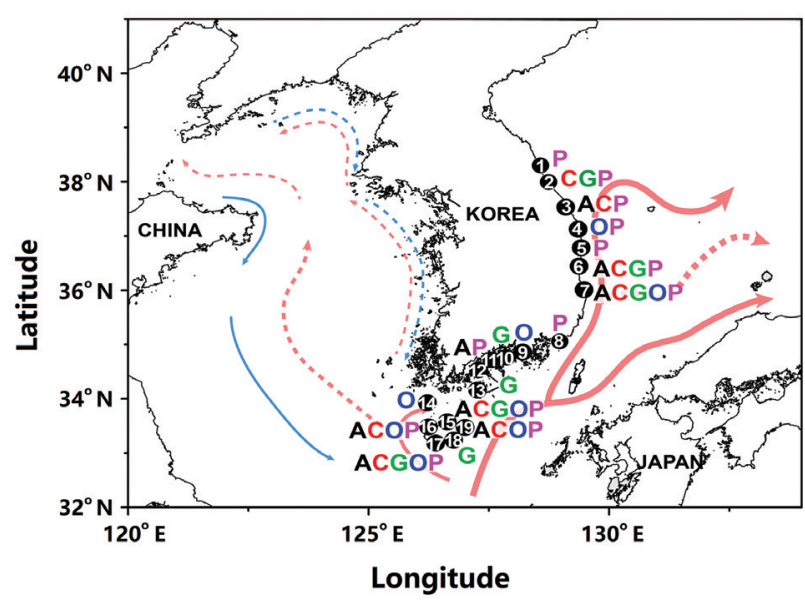

Fig. 2. Distribution of Amphidinium spp. (A in black), Prorocentrum spp. ( $\mathrm{P}$ in pink), Coolia spp. (C in red), Ostreopsis spp. (O in blue), and Gambierdiscus spp. ( $\mathrm{G}$ in green) in Korean waters. Blue lines indicate cold coastal currents and red lines indicate the warm Kuroshio Current and its branches. Sites: 1, Sokcho; 2, Yangyang; 3, Samcheok; 4, Uljin; 5, Wolsong; 6, Yeongdeok; 7, Pohang; 8, Busan; 9, Goseong; 10, Namhae; 11, Yeosu; 12, Goheung; 13, Baek Island; 14, Chuja Island; 15, Hamduck; 16, Hyupjae / Hamo; 17, Hwasun; 18, Seop Island; 19 , Sinyang / Kimnyung. Data were obtained from Baek (2012a, 2012b), Shah et al. (2013a, 2013b, 2014a), and Lee and Park (2018).

\section{GEOGRAPHICAL DISTRIBUTION OF BENTHIC DINOFLAGELLATES IN KOREAN WATERS}

Prior to 2009, Korean waters were not included among the locations where benthic dinoflagellates were found (Litaker et al. 2010, Kim et al. 2011, Rhodes 2011). Since the first report of all major genera of benthic dinoflagellates, Amphidinium, Coolia, Gambierdiscus, Ostreopsis, and Prorocentrum, in Korean waters (Kim et al. 2011), the number of studies on benthic dinoflagellates in Korean waters largely increased (Baek 2012a, 2012b, Jeong et al. 2012a, 2012b, Kang et al. 2013, Lee et al. 2013, Lim et al. 2013, Shah et al. 2013a, 2013b, 2014a, 2014b, Jang et al. 2018, Kim and Seo 2019, Lee and Park 2020, Park et al. 2020). Species belonging to these genera have been continuously reported in the South and the East Sea of Korea, including Jeju Island (Fig. 2). The Kuroshio Current begins east of the Philippines and flows northeastward, and its branches affect the South and the East Sea of Korea (Lie and Cho 2016). These currents have likely introduced benthic dinoflagellates living in tropical waters into the Korean temperate waters and facilitated their distribution along the Korean Peninsula as a result of the east-northward range expansion (Fig. 2). Under these circumstances, it is critical to determine whether these dinoflagellates can survive and overwinter in the South and
East Sea of Korea. One of the highest latitudes at which Coolia spp. were found in the Pacific Ocean is in the East Sea of Korea, whereas the highest latitude at which $\mathrm{Coo}$ lia spp. are found in the Atlantic Ocean is in Nieuwpoort, Belgium $\left(51.1^{\circ} \mathrm{N}\right.$ ) (Leaw et al. 2016). Before the presence of C. canariensis and C. malayensis in Korean waters was confirmed by Jeong et al. (2012b), the former had been found only in the Atlantic Ocean and Australian waters (Fraga et al. 2008, Laza-Martinez et al. 2011) and the latter only in Malaysia (Leaw et al. 2010, 2016). Therefore, the discovery of these two Coolia species in Korean waters extended the known distribution of $C$. canariensis and $C$. malayensis into the temperate waters of the North Pacific Ocean (Jeong et al. 2012b).

\section{HOST PREFERENCE AND ABUNDANCE OF BEN- THIC DINOFLAGELLATES IN KOREAN WATERS}

Amphidinium spp., Coolia spp., Gambierdiscus spp., Ostreopsis spp., and Prorocentrum spp. have been observed on the thalli of the following macroalgae collected from the South Sea and the East Sea: the chlorophytes Cladophora wrightiana and Ulva pertusa (Table 2), the phaeophytes Chordaria flagelliformis, Colpomenia sinuosa, Dictyopteris divaricata, D. prolifera, Ecklonia cava, Padina arborescens, Sargassum horneri, and Sargassum sp. (Table 3), and the rhodophytes Chondrus ocellatus, Gelidium amansii, Martensia sp., Plocamium telfairiae, and Pterocladiella capillacea (Table 4). Ostreopsis species were found on most macroalgae sampled, while Gambierdiscus were rarely found compared with the other benthic dinoflagellate genera (Tables 2-4). Furthermore, Kim et al. (2011) reported that the highest abundance of Ostreopsis spp. was found on the filamentous-shaped Derbesia sp. (Table 2), while Amphidinium, Coolia, Gambierdiscus, and Prorocentrum were most abundant on the sheet-like Martensia sp. (Table 4). Many studies have examined the host preferences of benthic dinoflagellates, but no clear correlation between the two has been established (Carlson et al. 1984, Bomber et al. 1989, Yong et al. 2018, Mustapa et al. 2019, Lee et al. 2020, Park et al. 2020). For example, Bomber et al. (1989) and Carlson et al. (1984) reported the greatest abundance of G. toxicus on the sheet-like and slippery macroalga Dictyota dichotoma in waters of the Florida Keys and Virgin Islands. In contrast, Parsons and Preskitt (2007) found that Gambierdiscus sp. and P. lima preferred a filamentous host, whereas Ostreopsis sp. favored sheet-like macroblades.

Some macroalgae have been suggested as unfavor- 
able hosts for some benthic dinoflagellates. For instance, Parsons and Preskitt (2007) reported that the rhodophyte Tolypiocladia glomerulata may be a poor host for O. ovata. Similarly, the chlorophyte Ulva rigida, the phaeophyte D. dichotoma, and the rhodophyte Rhodymenia pseudopalmata negatively affected the growth of Ostreopsis cf. ovata (Accoroni et al. 2015, Ben Gharbia et al. 2017). Therefore, allelopathic effects by macroalgae on certain benthic dinoflagellate species may affect host selectivity by the latter as well as the morphology of the former. More studies on the allelopathic effects of macroalgae on benthic dinoflagellates are required to understand host selectivity by benthic dinoflagellates.

The maximum abundance of Coolia spp. $\left(0.7 \times 10^{3}\right.$ cells $\mathrm{g}^{-1}$ wet weight $[\mathrm{ww}]$ ) (Table 5) in Korean waters is much lower than that reported for C. monotis in the

Table 2. The abundance (cells $\mathrm{g}^{-1}$ wet weight) of benthic dinoflagellates (Amphidinium spp., Coolia spp., Gambierdiscus spp., Ostreopsis spp., and Prorocentrum spp.) living on the thalli of diverse Chlorophyta collected from the coast of Jeju Island and the southern coast of Korea

\begin{tabular}{|c|c|c|c|c|c|c|c|c|}
\hline Chlorophyta & $\begin{array}{l}\text { Surface } \\
\text { types }\end{array}$ & Morphology & $\begin{array}{l}\text { Amphi- } \\
\text { dinium }\end{array}$ & Coolia & $\begin{array}{l}\text { Gambier- } \\
\text { discus }\end{array}$ & Ostreopsis & $\begin{array}{l}\text { Prorocen- } \\
\quad \text { trum }\end{array}$ & Reference \\
\hline Cladophora japonica & $\mathrm{H}$ & FI & NA & NA & 56.37 & NA & NA & Baek $(2012 b)$ \\
\hline C. wrightiana & $\mathrm{H}$ & FI & $0-22$ & 6 & 39 & $102-758$ & $0-6$ & $\begin{array}{l}\text { Kim et al. (2011), Shah et al. } \\
(2013 b)\end{array}$ \\
\hline $\begin{array}{l}\text { Cladophoropsis } \\
\text { herpestica }\end{array}$ & $\mathrm{H}$ & FI & 0 & 0 & 173 & 231 & 0 & Kim et al. (2011) \\
\hline Codium fragile & $\mathrm{H}$ & $\mathrm{AR}$ & 25 & 0 & 0 & 21 & 8 & $\begin{array}{l}\text { Kim et al. (2011), Shah et al. } \\
(2013 b)\end{array}$ \\
\hline Derbesia sp. & S & FI & 0 & 0 & 1,595 & 8,660 & 0 & Kim et al. (2011) \\
\hline Enteromorpha linza & S & FO & 14 & 4 & 0 & 57 & 25 & Shah et al. $(2013 b)$ \\
\hline Ulva pertusa & S & FO & 23 & $3-237$ & $0-500$ & $52-342$ & $8-53$ & $\begin{array}{l}\text { Kim et al. (2011), Baek } \\
(2012 b) \text {, Shah et al. }(2013 b)\end{array}$ \\
\hline
\end{tabular}

H, hard; FI, filamentous; NA, not available; AR, arborescent; S, slippery; FO, foliaceous.

Table 3. The abundance (cells $\mathrm{g}^{-1}$ wet weight) of benthic dinoflagellates (Amphidinium spp., Coolia spp., Gambierdiscus spp., Ostreopsis spp., and Prorocentrum spp.) living on the thalli of diverse Phaeophyta collected from the coast of Jeju Island and the southern coast of Korea

\begin{tabular}{|c|c|c|c|c|c|c|c|c|}
\hline Phaeophyta & $\begin{array}{c}\text { Surface } \\
\text { types }\end{array}$ & Morphology & $\begin{array}{l}\text { Amphi- } \\
\text { dinium }\end{array}$ & Coolia & $\begin{array}{l}\text { Gambier- } \\
\text { discus }\end{array}$ & Ostreopsis & $\begin{array}{l}\text { Prorocen- } \\
\text { trum }\end{array}$ & Reference \\
\hline $\begin{array}{l}\text { Chordaria flagellifor- } \\
\text { mis }\end{array}$ & S & FI & $0-121$ & $0-339$ & 1,770 & 364 & 97 & Kim et al. (2011) \\
\hline Champia expansa & S & FO & 35 & 30 & 0 & 48 & 15 & Shah et al. (2013b) \\
\hline Colpomenia sinuosa & $S$ & FO & $0-68$ & 11 & 136 & $32-545$ & 23 & $\begin{array}{l}\text { Kim et al. (2011), Shah et al. } \\
(2013 b)\end{array}$ \\
\hline $\begin{array}{c}\text { Dictyopteris } \\
\text { divaricata }\end{array}$ & S & FO & $0-37$ & 15 & $0-200$ & $12-216$ & $6-12$ & $\begin{array}{l}\text { Kim et al. (2011), Shah et al. } \\
(2013 b)\end{array}$ \\
\hline D. prolifera & S & FO & 33 & 38 & $1-60$ & $43-164$ & $0-16$ & $\begin{array}{l}\text { Kim et al. (2011), Baek } \\
(2012 b) \text {, Shah et al. }(2013 b)\end{array}$ \\
\hline D. undulata & $\mathrm{S}$ & FO & 0 & 0 & 62 & NA & 0 & Kim et al. (2011) \\
\hline Dictyota okamurae & $\mathrm{S}$ & FO & 0 & 0 & 1,000 & 185 & 0 & Kim et al. (2011) \\
\hline Ecklonia cava & $\mathrm{S}$ & FO & $0-23$ & $2-33$ & $0-53$ & $0.4-69$ & $0-8$ & $\begin{array}{l}\text { Kim et al. (2011), Baek } \\
(2012 b), \text { Shah et al. }(2013 b\end{array}$ \\
\hline Hizikia fusiformis & S & $\mathrm{AR}$ & 5 & 42 & 0 & 69 & 25 & Shah et al. $(2013 b)$ \\
\hline Padina arborescens & $\mathrm{S}$ & FO & $0-137$ & $0-652$ & $8-789$ & 583 & 171 & $\begin{array}{l}\text { Kim et al. (2011), Baek } \\
(2012 b)\end{array}$ \\
\hline Sargassum confusum & $\mathrm{S}$ & $\mathrm{AR}$ & 8 & 18 & 0 & 19 & 36 & Shah et al. $(2013 b)$ \\
\hline S. honeri & S & $\mathrm{AR}$ & 22 & 24 & $0-1.33$ & 57 & 28 & $\begin{array}{l}\text { Baek }(2012 b) \text {, Shah et al. } \\
(2013 b)\end{array}$ \\
\hline S. macrocarpum & $\mathrm{S}$ & $\mathrm{AR}$ & 11 & 30 & 0 & 49 & 23 & Shah et al. $(2013 b)$ \\
\hline S. thunbergii & S & FI & 19 & 23 & 0 & $0.5-25$ & 23 & $\begin{array}{l}\text { Shah et al. }(2013 b) \text {, Kim and } \\
\text { Seo (2019) }\end{array}$ \\
\hline S. siliquastrum & $S$ & $\mathrm{AR}$ & $0-6$ & $0-17$ & 0 & $37-121$ & $0-27$ & $\begin{array}{l}\text { Kim et al. (2011), Shah et al. } \\
(2013 b)\end{array}$ \\
\hline Sargassum sp. & $\mathrm{S}$ & $\mathrm{AR}$ & $0-10$ & $0-121$ & 343 & 434 & 30 & Kim et al. (2011) \\
\hline $\begin{array}{l}\text { Scytosiphon lomen- } \\
\text { taria }\end{array}$ & S & FI & NA & NA & NA & 1 & NA & Kim and Seo (2019) \\
\hline Undaria pinnatifida & $S$ & FO & NA & NA & $0-10$ & NA & NA & Baek $(2012 b)$ \\
\hline Zonaria diesingiana & $\mathrm{S}$ & FO & 0 & 0 & 111 & $44-94$ & 0 & Kim et al. (2011) \\
\hline
\end{tabular}

S, slippery; FI, filamentous; FO, foliaceous; NA, not available; AR, arborescent. 
northwestern Mediterranean Sea $\left(143 \times 10^{3}\right.$ cells g $\left.^{-1} \mathrm{ww}\right)$ (Table 5) (Vila et al. 2001). The maximum abundance of Gambierdiscus spp. $\left(\sim 5 \times 10^{3}\right.$ cells g $\left.^{-1} \mathrm{ww}\right)$ obtained from the waters off Jeju Island is lower than that in New South Wales, Australia $\left(8 \times 10^{3}\right.$ cells $\left.\mathrm{g}^{-1} \mathrm{ww}\right)$ (Table 5) (Kohli et al. 2014). The maximum abundance of Ostreopsis spp. $\left(\sim 9 \times 10^{3}\right.$ cells $\left.\mathrm{g}^{-1} \mathrm{ww}\right)$ on Derbesia sp. in Korean waters is much lower than those reported in other subtropical or temperate locations $\left(14 \times 10^{5}\right.$ cells $\left.^{-1}{ }^{-1 w}\right)$ (Table 5). The maximum abundance of Prorocentrum spp. $\left(\sim 0.3 \times 10^{3}\right.$ cells $\mathrm{g}^{-1} \mathrm{ww}$ ) in Korean waters is lower than that in Florida $\left(1.3 \times 10^{3}\right.$ cells g $\left.^{-1} \mathrm{ww}\right)$, but similar to that in the subtropical regions of Okinawa, Japan (Table 5). This evidence suggests that the abundance of these benthic genera may be lower in temperate Korean waters than in subtropical and other temperate waters. Environmental conditions, such as water temperature or nutrient concentrations around Korea, may still be less favorable for these five benthic dinoflagellate genera compared with the conditions in subtropical and other temperate waters.

\section{GRAZERS OF BENTHIC DINOFLAGELLATES IN KOREAN WATERS}

Grazers are known to influence the abundance of ben-

Table 4. The abundance (cells ${ }^{-1}$ wet weight) of benthic dinoflagellates (Amphidinium spp., Coolia spp., Gambierdiscus spp., Ostreopsis spp., and Prorocentrum spp.) living on the thalli of diverse Rhodophyta collected from the coast of Jeju Island and the southern coast of Korea

\begin{tabular}{|c|c|c|c|c|c|c|c|c|}
\hline Rhodophyta & $\begin{array}{l}\text { Surface } \\
\text { types }\end{array}$ & Morphology & $\begin{array}{l}\text { Amphi- } \\
\text { dinium }\end{array}$ & Coolia & $\begin{array}{l}\text { Gambier- } \\
\text { discus }\end{array}$ & Ostreopsis & $\begin{array}{l}\text { Prorocen- } \\
\text { trum }\end{array}$ & Reference \\
\hline $\begin{array}{l}\text { Agarophyton ver- } \\
\text { miculophyllum } \\
\text { (= Gracilaria ver- } \\
\text { miculophylla) }\end{array}$ & S & FI & 8 & 14 & 0 & 52 & 24 & Shah et al. $(2013 b)$ \\
\hline Amphiroa anceps & $\mathrm{H}$ & $\mathrm{AR}$ & NA & NA & 20 & NA & NA & Baek $(2012 b)$ \\
\hline $\begin{array}{l}\text { Ahnfeltiopsis flabel- } \\
\text { liformis }\end{array}$ & $\mathrm{S}$ & $\mathrm{AR}$ & NA & NA & NA & 28 & NA & Kim and Seo (2019) \\
\hline $\begin{array}{l}\text { Chondrus canalicu- } \\
\text { latus }\end{array}$ & S & $\mathrm{AR}$ & 23 & 8 & 0 & 49 & 22 & Shah et al. (2013b) \\
\hline C. ocellatus & S & FO & $0-27$ & $0-47$ & $0-63$ & $35-267$ & $0-39$ & $\begin{array}{l}\text { Kim et al. (2011), Shah et al. } \\
(2013 b)\end{array}$ \\
\hline Corallina pilulifera & $\mathrm{H}$ & $\mathrm{AR}$ & 16 & 7 & 0 & 40 & 13 & Shah et al. $(2013 b)$ \\
\hline Corallina sp. & $\mathrm{H}$ & $\mathrm{AR}$ & 0 & 0 & 33-993 & $28-307$ & 33 & Kim et al. (2011) \\
\hline Galaxaura apiculata & $\mathrm{H}$ & $\mathrm{AR}$ & 8 & 26 & 0 & 48 & 22 & Shah et al. $(2013 b)$ \\
\hline G. falcate & $\mathrm{H}$ & $\mathrm{AR}$ & 21 & 23 & 0 & 50 & 21 & Shah et al. $(2013 b)$ \\
\hline Gelidium amansii & $\mathrm{S}$ & $\mathrm{AR}$ & $0-13$ & $0-21$ & $4-426$ & $3-688$ & $24-233$ & $\begin{array}{l}\text { Kim et al. (2011), Baek } \\
(2012 b) \text {, Shah et al. (2013b), } \\
\text { Kim and Seo (2019) }\end{array}$ \\
\hline $\begin{array}{l}\text { Gracilaria bursa- } \\
\text { pastoris }\end{array}$ & $S$ & $\mathrm{AR}$ & NA & NA & NA & 2 & NA & Kim and Seo (2019) \\
\hline G. textorii & S & FO & NA & NA & $0-6$ & NA & NA & Baek $(2012 b)$ \\
\hline Gracilaria sp. & S & $\mathrm{AR}$ & 21 & 16 & 0 & 38 & 16 & Shah et al. $(2013 b)$ \\
\hline Grateloupia angusta & S & $\mathrm{AR}$ & NA & NA & $0-24$ & NA & NA & Baek $(2012 b)$ \\
\hline G. asiatica & $S$ & $\mathrm{AR}$ & 16 & 22 & 0 & 46 & 17 & Shah et al. $(2013 b)$ \\
\hline G. filicina & S & $\mathrm{AR}$ & NA & NA & NA & $2-158$ & NA & Kim and Seo (2019) \\
\hline Hypnea charoides & S & $\mathrm{AR}$ & 12 & 28 & 0 & 48 & 20 & Shah et al. $(2013 b)$ \\
\hline $\begin{array}{l}\text { Jania pedunculata } \\
\text { var. adhaerens }\end{array}$ & $\mathrm{H}$ & $\mathrm{AR}$ & 0.7 & 27 & 0 & 75 & 28 & Shah et al. $(2013 b)$ \\
\hline Laurencia okamurae & $\mathrm{H}$ & $\mathrm{AR}$ & NA & NA & NA & 35 & NA & Kim and Seo (2019) \\
\hline Lithothamnion sp. & $\mathrm{H}$ & $\mathrm{AR}$ & 0 & 0 & 25 & NA & 0 & Kim et al. (2011) \\
\hline Martensia sp. & $S$ & FO & $0-406$ & $0-710$ & $0-4,871$ & $10-3,349$ & 23-304 & $\begin{array}{l}\text { Kim et al. (2011), Shah et al. } \\
(2013 b)\end{array}$ \\
\hline $\begin{array}{l}\text { Plocamium cartilag- } \\
\text { ineum }\end{array}$ & S & $\mathrm{AR}$ & 0 & 0 & 255 & 255 & 0 & Kim et al. (2011) \\
\hline P. telfairiae & S & $\mathrm{AR}$ & $0-13$ & $0-24$ & $0-1,477$ & $50-966$ & $0-31$ & $\begin{array}{l}\text { Kim et al. (2011), Shah et al. } \\
(2013 b)\end{array}$ \\
\hline $\begin{array}{l}\text { Polysiphonia mor- } \\
\text { rowii }\end{array}$ & S & FO & NA & NA & NA & 7 & NA & Kim and Seo (2019) \\
\hline $\begin{array}{l}\text { Pterocladiella capol- } \\
\text { lacea }\end{array}$ & S & $\mathrm{AR}$ & $0-18$ & $0-23$ & $0-1,599$ & $50-837$ & $0-38$ & $\begin{array}{l}\text { Kim et al. (2011), Shah et al. } \\
(2013 b)\end{array}$ \\
\hline Wrangelia tanegana & $\mathrm{H}$ & $\mathrm{AR}$ & 20 & 10 & 0 & 33 & 15 & Shah et al. $(2013 b)$ \\
\hline
\end{tabular}

$\mathrm{S}$, slippery; FI, filamentous; $\mathrm{H}$, hard; AR, arborescent; NA, not available; FO, foliaceous. 
thic dinoflagellates (Yoo et al. 2015, Pavaux et al. 2020, You et al. 2020). Some mixotrophic and heterotrophic dinoflagellates, ciliates, and heterotrophic nanoflagellates have been shown to feed on the Korean strains of several benthic dinoflagellates, such as Ostreopsis cf. ovata, Coolia spp., G. jejuensis (previously reported as G. caribaeus in Jeong et al. 2012a, 2016, Kwon et al. 2017, Lim et al. 2018, Ok et al. 2018), and P. lima (Table 6); the heterotrophic dinoflagellates Gyrodinium moestrupii and Polykrikos kofoidii can feed on O. cf. ovata OVJJ1, exhibiting higher ingestion rates when feeding on $O$. cf. ovata than on other prey species (Yoo et al. 2015). C. canariensis CCJJ1 and C. malayensis CMJJ2 were fed by the mixotrophic dinoflagellates Takayama helix and T. tasmanica and the heterotrophic nanoflagellate Katablepharis japonica (Jeong et al. 2016, Kwon et al. 2017, Lim et al. 2018) (Table 6). Furthermore, G. jejuensis GCJJ1 was fed by T. helix and T. tasmanica (Table 6). Benthic dinoflagellates, especially Ostreopsis, can detach easily from substrates and float in the water column (Mangialajo et al. 2011, Pavaux et al. 2020). Korea experiences tropical cyclones almost annually (http://www.weather.go.kr). Thus, the vigorous water-mixing driven by tropical cyclones can release the benthic dinoflagellate cells into the water column, which temporarily increases the abundance of benthic dinoflagellates in the water column. Under these circumstances, diverse grazers can feed on benthic dinoflagellates and have a considerable impact on their populations.

\section{TOXICITY}

The Korean strains of some benthic dinoflagellates isolated from waters off Jeju Island have been revealed to have toxic compounds and show toxicity (Table 7). The A. operculatum HLAM2 strain exerts cytotoxicity to murine macrophage cells and human tumor cells (Table 7) (Shah et al. 2014b). The two strains O. cf. ovata OVJJ1

Table 5. Comparison of the maximum abundances (MA, cells $\mathrm{g}^{-1}$ wet weight) of benthic dinoflagellates in the genera Amphidinium, Coolia, Gambierdiscus, Ostreopsis, and Prorocentrum reported from the waters of temperate and subtropical-temperate regions

\begin{tabular}{|c|c|c|c|}
\hline Species & Location & MA & Reference \\
\hline \multirow[t]{2}{*}{ Coolia spp. } & Jeju Island, Korea & 710 & Kim et al. (2011) \\
\hline & South-East Sea, Korea & 3 & Baek $(2012 a)$ \\
\hline \multirow[t]{2}{*}{ C. monotis } & North Aegean Sea, Greece & 16,000 & Aligizaki and Nikolaidis (2006) \\
\hline & NW Mediterranean Sea & 143,000 & Vila et al. (2001) \\
\hline \multirow[t]{5}{*}{ Gambierdiscus spp. } & Back Islands, Korea & 20 & Baek $(2012 b)$ \\
\hline & Jeju Island, Korea & 56 & Baek $(2012 b)$ \\
\hline & Jeju Island, Korea & 4,870 & Kim et al. (2011) \\
\hline & South-East Sea, Korea & 10 & Baek $(2012 a)$ \\
\hline & New South Wales, Australia & 8,255 & Kohli et al. (2014) \\
\hline G. toxicus & Knight key, Florida & 2,279 & Bomber et al. (1989) \\
\hline \multirow[t]{3}{*}{ Ostreopsis spp. } & Jeju Island, Korea & 8,660 & Kim et al. (2011) \\
\hline & Pohang, Korea & 1,588 & Lee and Park (2018) \\
\hline & Jeju Island, Korea & 158 & Kim and Seo (2019) \\
\hline Ostreopsis sp. & South-East Sea, Korea & 140 & Baek $(2012 a)$ \\
\hline Ostreopsis spp. & Peter the Great Bay & 71,000 & Selina et al. (2014) \\
\hline Ostreopsis cf. ovata & Jeju Island, Korea & 3,204 & Park et al. (2020) \\
\hline Ostreopsis sp. & NW Mediterranean Sea & 596,000 & Vila et al. (2001) \\
\hline \multirow[t]{2}{*}{ O. siamensis } & Auckland, New Zealand & $1,400,000$ & Shears and Ross (2009) \\
\hline & Knight key, Florida & 308 & Bomber et al. (1989) \\
\hline O. heptagona & Knight key, Florida & 394 & Bomber et al. (1989) \\
\hline Ostreopsis spp. & North Aegean Sea, Greece & 405,000 & Aligizaki and Nikolaidis (2006) \\
\hline Prorocentrum spp. & Jeju Island, Korea & 304 & Kim et al. (2011) \\
\hline Prorocentrum lima & South-East Sea, Korea & 52 & Baek $(2012 a)$ \\
\hline P. concavum & Knight key, Florida & 133 & Bomber et al. (1989) \\
\hline P. mexicanum & Knight key, Florida & 844 & Bomber et al. (1989) \\
\hline P. lima & Knight key, Florida & 1,379 & Bomber et al. (1989) \\
\hline \multirow[t]{2}{*}{ Prorocentrum spp. } & Kochi, Tosa Bay, Japan & 29 & Nishimura et al. (2020) \\
\hline & Okinawa, Nakagusuku Bay, Japan & 267 & Nishimura et al. (2020) \\
\hline \multirow{2}{*}{ Amphidinium spp. } & Jeju Island, Korea & 406 & Kim et al. (2011) \\
\hline & South-East Sea, Korea & 2 & Baek (2012a) \\
\hline
\end{tabular}

Bold letters indicate highest maximum abundance reported for each genus. 
Table 6. Predators of the Korean strains of benthic dinoflagellates reported to date

\begin{tabular}{|c|c|c|c|c|c|}
\hline Benthic dinoflagellate (strain) & Predator group & Predator species (strain) & Feeding & GR & Reference \\
\hline \multirow[t]{9}{*}{ Ostreopsis cf. ovata (OVJJ1) } & HTD & Gyrodinium dominans & $\mathrm{Y}$ & Negative & Yoo et al. (2015) \\
\hline & HTD & Gyrodinium moestrupii & $\mathrm{Y}$ & $0.862^{\mathrm{a}}$ & Yoo et al. (2015) \\
\hline & HTD & Gyrodinium spirale & $\mathrm{N}$ & NG & Yoo et al. (2015) \\
\hline & HTD & Oxyrrhis marina & $\mathrm{Y}$ & Negative & Yoo et al. (2015) \\
\hline & HTD & Polykrikos kofoidii & $\mathrm{Y}$ & $0.725^{\mathrm{a}}$ & Yoo et al. (2015) \\
\hline & Ciliate & Strobilidium sp. & $\mathrm{N}$ & NG & Yoo et al. (2015) \\
\hline & HTD & Pfiesteria piscicida & $\mathrm{Y}$ & Negative & Yoo et al. (2015) \\
\hline & HTD & Stoeckeria algicida & $\mathrm{N}$ & NG & Yoo et al. (2015) \\
\hline & HTD & Protoperidinium bipes & $\mathrm{N}$ & NG & Yoo et al. (2015) \\
\hline \multirow{2}{*}{ Coolia canariensis (CCJJ1) } & MTD & Takayama helix (CCMP3082) & $\mathrm{Y}$ & NA & Jeong et al. (2016) \\
\hline & MTD & Takayama tasmanica (CAWD115) & $\mathrm{Y}$ & NA & Lim et al. (2018) \\
\hline \multirow[t]{4}{*}{ Coolia malayensis (CMJJ2) } & MTD & Takayama helix (CСMP3082) & $\mathrm{Y}$ & NA & Jeong et al. (2016) \\
\hline & MTD & Takayama tasmanica (CAWD115) & $\mathrm{Y}$ & NA & Lim et al. (2018) \\
\hline & HNF & Katablepharis japonica (KJMS1610) & $\mathrm{Y}$ & NA & Kwon et al. (2017) \\
\hline & HNF & Katablepharis remigera (KRJH1707) & $\mathrm{N}$ & NG & Ok et al. (2018) \\
\hline \multirow{4}{*}{$\begin{array}{l}\text { Gambierdiscus jejuensis } \\
\text { (= previously reported as } \\
\text { G. caribaeus GCJJ1) }\end{array}$} & MTD & Takayama helix (CCMP3082) & $\mathrm{Y}$ & NA & Jeong et al. (2016) \\
\hline & MTD & Takayama tasmanica (CAWD115) & $\mathrm{Y}$ & NA & Lim et al. (2018) \\
\hline & HNF & Katablepharis japonica (KJMS1610) & $\mathrm{N}$ & NG & Kwon et al. (2017) \\
\hline & HNF & Katablepharis remigera (KRJH1707) & $\mathrm{N}$ & NG & Ok et al. (2018) \\
\hline \multirow[t]{6}{*}{ Prorocentrum lima (DF-114) } & HTD & Pfiesteria piscicida (CCMP2091) & $\mathrm{Y}^{\mathrm{b}}$ & NA & You et al. (2020) \\
\hline & HTD & Oxyrrhis marina & $\mathrm{N}$ & NA & You et al. (2020) \\
\hline & HTD & Gyrodinium dominans & $\mathrm{Y}$ & -0.193 & You et al. (2020) \\
\hline & HTD & Oblea rotunda & $\mathrm{N}$ & NA & You et al. (2020) \\
\hline & HTD & Polykrikos kofoidii & $\mathrm{Y}$ & -0.2 & You et al. (2020) \\
\hline & Ciliate & Strombidinopsis sp. & $\mathrm{Y}$ & NA & You et al. (2020) \\
\hline
\end{tabular}

GR, growth rate $\left(d^{-1}\right)$ of each predator; HTD, heterotrophic dinoflagellate; $Y$, able to feed on benthic dinoflagellate; $N$, not able to feed on benthic dinoflagellate; NG, no growth; MTD, mixotrophic dinoflagellate; NA, not available; HNF, heterotrophic nanoflagellate.

${ }^{\mathrm{a}}$ Maximum growth rate.

${ }^{\mathrm{b}}$ Able to feed only on motionless prey cells.

Table 7. Toxicity of the strains of benthic dinoflagellates isolated from waters off Jeju Island, Korea

\begin{tabular}{|c|c|c|c|}
\hline Species & Target for toxicity test & Toxicity / Active compound & Reference \\
\hline Amphidinium carterae (JHWAC) & $\begin{array}{l}\text { Murine macrophage cell, human } \\
\text { promyelocytic leukemia tumor cell }\end{array}$ & NT & Shah et al. $(2014 b)$ \\
\hline A. massartii (AMJJ1) & Brine shrimp & NT & Lee et al. (2013) \\
\hline A. operculatum (HLAM2) & $\begin{array}{l}\text { Murine macrophage cell, human } \\
\text { promyelocytic leukemia tumor cell }\end{array}$ & Cytotoxicity & Shah et al. $(2014 b)$ \\
\hline A. operculatum (SIAM1) & $\begin{array}{l}\text { Murine macrophage cell, human } \\
\text { promyelocytic leukemia tumor cell }\end{array}$ & NT & Shah et al. $(2014 b)$ \\
\hline Coolia malayensis (JHACO6) & $\begin{array}{l}\text { Murine macrophage cell, human } \\
\text { promyelocytic leukemia tumor cell }\end{array}$ & NT & Shah et al. $(2014 b)$ \\
\hline C. malayensis (JHWCO1) & $\begin{array}{l}\text { Murine macrophage cell, human } \\
\text { promyelocytic leukemia tumor cell }\end{array}$ & NT & Shah et al. $(2014 b)$ \\
\hline C. malayensis (JHLCO6) & $\begin{array}{l}\text { Murine macrophage cell, human } \\
\text { promyelocytic leukemia tumor cell }\end{array}$ & NT & Shah et al. $(2014 b)$ \\
\hline Gambierdiscus jejuensis (GJ1703a) & Brine shrimp & NT & Our unpublished data \\
\hline Gambierdiscus sp. & Copepod & Mortality of nauplii & Lee et al. (2014) \\
\hline Ostreopsis cf. ovata (OVJJ1) & Brine shrimp & Cytotoxicity / Ostreol A & Hwang et al. (2013) \\
\hline O. cf. ovata (OVJJ1) & $\begin{array}{l}\text { Hepatocarcinoma, neuroblastoma, } \\
\text { colon cancer cells }\end{array}$ & Cytotoxicity / Ostreol B & Hwang et al. (2018) \\
\hline O. ovata (JHAOS5) & $\begin{array}{l}\text { Murine macrophage cell, human } \\
\text { promyelocytic leukemia tumor cell }\end{array}$ & Cytotoxicity & Shah et al. $(2014 b)$ \\
\hline O. ovata (JHWOS13) & $\begin{array}{l}\text { Murine macrophage cell, human } \\
\text { promyelocytic leukemia tumor cell }\end{array}$ & NT & Shah et al. $(2014 b)$ \\
\hline Prorocentrum lima (Plima-YD-5) & $\begin{array}{l}\text { Hepatocarcinoma, neuroblastoma, } \\
\text { colon cancer cells }\end{array}$ & Cytotoxicity / Limaol & $\begin{array}{l}\text { Yang et al. (2017), } \\
\text { Lee et al. (2019) }\end{array}$ \\
\hline P. rhathymum (JHWPMX1) & $\begin{array}{l}\text { Murine macrophage cell, human } \\
\text { promyelocytic leukemia tumor cell }\end{array}$ & NT & Shah et al. $(2014 b)$ \\
\hline
\end{tabular}

NT, non-toxic. 
and O. ovata JHAOS5 exhibit cytotoxicity toward brine shrimp and / or cell lines (Hwang et al. 2013, 2018, Shah et al. 2014b); ostreol A and B from O. cf. ovata OVJJ1 were identified as new active compounds (Hwang et al. 2013, 2018). The strain P. lima Plima-YD-5 similarly exhibited cytotoxicity toward cell lines, and limaol was isolated from this strain (Yang et al. 2017, Lee et al. 2019). Gambierdiscus sp. is toxic to a copepod (Lee et al. 2014), but $G$. jejuensis GJ1703a shows no toxicity toward brine shrimp Artemia salina (unpublished data).

The Korean strains of C. malayensis (JHACO6, JHWCO1, and JHLCO6) did not exhibit cytotoxicity toward murine macrophage cells and human tumor cells (Shah et al. 2014b), although the C. malayensis (previously $C$. monotis) strain isolated from other temperate regions, such as New Zealand, has been reported to have toxic effects on the larvae of Artemia salina and Haliotis virginea (Rhodes and Thomas 1997) (Table 7). Therefore, there may be differences in toxicity levels between different $C$. malayensis strains.

Among these toxic benthic dinoflagellate strains, the cultures of P. lima Plima-YD-5 and O. cf. ovata OVJJ1 were established from the cells detached from the thalli of popular edible macroalgae Sargassum fulvellum and G. amansii, respectively (Hwang et al. 2013, Yang et al. 2017, Hwang and Park 2020). Along the coastal waters of the Korean Peninsula, there are many regions where S. fulvellum and G. amansii are naturally abundant or largely cultivated (Hwang and Park 2020, Korea Fisheries Resources Agency 2020). The area along the coast of the Korean Peninsula that was covered by a seaweed aquaculture, reached approximately 21,490 ha by the end of 2019 (Korea Fisheries Resources Agency 2020). These seaweed farms may provide habitats for these benthic dinoflagellates. It is, therefore, worthwhile to monitor the toxin concentrations produced by these dinoflagellates in the waters of the eastern, western, and northern parts of Korea.

\section{ECOLOGICAL, ECONOMIC, AND SOCIAL IMPOR- TANCE OF THE PRESENCE OF BENTHIC DINO- FLAGELLATES IN KOREAN WATERS}

\section{Signal for an increase in the temperature of Korean coastal waters}

Over several decades, the sea surface temperature (SST) around Korea has increased at an accelerated rate owing to global warming. For example, the annual aver- age SST increased by $0.07^{\circ} \mathrm{C}$ for 80 years, from 1916 to 1995 (Kang 2000). A recent study reported the annual average SST increase of $1.23^{\circ} \mathrm{C}$ from 1968 to 2018; this increasing SST trend was particularly dominant during winter (Han and Lee 2020). The rate of change became more pronounced in recent decades than it was during the past 80 years, which implies that the coastal SST in Korea has a tendency to shift from temperate to that typical for the subtropical climate zone. Such warming in Korean coastal waters may cause the northward expansion of tropical and subtropical benthic dinoflagellate species. For example, Coolia tropicalis has been found only in tropical waters of Malaysia to date (Leaw et al. 2016). However, the C. tropicalis UTSHIID5 strain isolated from Australia can survive in temperatures as low as $10^{\circ} \mathrm{C}$ (Table 8) (Larsson et al. 2019). From 1984 to 2013, the average SST in the South Sea of Korea in February and December was more than $10^{\circ} \mathrm{C}$ and as high as $19^{\circ} \mathrm{C}$ around Jeju Island (Kwak et al. 2015). If this strain is accidentally introduced in the temperate waters of Korea via water currents or the ballast waters of ships, it may overwinter and survive in the Korean coastal waters. Some other tropical species such as Coolia palmyrensis and Gambierdiscus ruetzleri, which have not been found yet in Korean waters, can survive below $17^{\circ} \mathrm{C}$ (Tables 8 \& 9). These dinoflagellates, previously not reported in Korean waters, may appear in the near future; thus, it would be worthwhile to monitor the presence of such benthic dinoflagellates regularly and to explore the conditions necessary for their survival during the winter season.

\section{Possible risks to human health}

Some Gambierdiscus, Prorocentrum, Ostreopsis, Amphidinium, and Coolia species are known to cause ciguatera fish poisoning, while some Prorocentrum species can cause diarrhetic shellfish poisoning (Ibrahim 2007, Tester et al. 2020). In some benthic dinoflagellates, such as $O$. ovata and $O$. cf. ovata, the toxin concentration per cell tends to become highest at the suboptimal temperatures, although the peak growth rate is achieved at a higher temperature (Granéli et al. 2011, Pezzolesi et al. 2012). Therefore, the impact of toxins may be greater in temperate waters than in subtropical or tropical waters when toxic benthic dinoflagellates proliferate. Koreans enjoy eating raw finfish, shellfish, and seaweeds, and the seaweed aquaculture industry in Korea has expanded (Korea Fisheries Resources Agency 2020). The Ministry of Oceans and Fisheries of the Korean government reported that in 2019, the seaweed aquaculture covered an area of 
90,421 ha and produced $1,812,213$ tons of seaweed worth 789 million USD (Ministry of Oceans and Fisheries 2020). In addition, the shellfish aquaculture accounted for approximately $27 \%$ of all sea farming in Korea, with 527,443 tons of shellfish produced in 2019 (Ministry of Oceans and Fisheries 2020). The discovery of these potentially toxic benthic dinoflagellates in Korean waters may cause Koreans to reduce their seaweed and shellfish consumption, which may incur great financial losses for related industries. Therefore, it is worthwhile to investigate the distribution of these benthic dinoflagellates along the entire coast of Korea.

\section{Caution is required in the establishment of un- derwater macroalgal forests}

In 2009, the Korean government began construct- ing marine forests to recover the marine ecosystem by providing habitats for sea animals (Korea Fisheries Resources Agency 2020). A total of 21,490 ha of macroalgal and seagrass forests were constructed along the eastern, western, and southern coasts of Korea and around Jeju Island (Korea Fisheries Resources Agency 2020). The construction of the marine forests that will cover an area of 54,000 ha is planned to be finished by 2030 (Korea Fisheries Resources Agency 2020). Macroalgal species such as Eisenia bicyclis, E. cava, Sargassum spp., Undaria pinnatifida, Agarophyton vermiculophyllum, Codium fragile, and seagrass Zostera spp. have been planted in these macroalgal forests; among these, only the seagrass species are non-edible (Table 10). It is likely that some of these algae will be used for human consumption. Many of the macroalgae planted in the marine forest of Korea may harbor potentially toxic epiphytic dinoflagel-

Table 8. Water temperature $(\mathrm{T})$ range that allow the survival of benthic Coolia and Ostreopsis species living in the waters of Korea and other countries

\begin{tabular}{|c|c|c|c|c|}
\hline Species (strain) & Climate & Location & $\mathrm{T}\left({ }^{\circ} \mathrm{C}\right)$ & Reference \\
\hline Coolia monotis & Temperate & East Sea, Korea & $16.3-35.0$ & Sung (2015) \\
\hline C. malayensis (UTSMER17A5) & Temperate & Merimbula Lake, NSW, Australia & $14.9-30.1$ & Larsson et al. (2019) \\
\hline C. malayensis (UTSMER17A6) & Temperate & Merimbula Lake, NSW, Australia & $14.5-30.2$ & Larsson et al. (2019) \\
\hline C. malayensis (SKLMP_S020) & Tropical & Hong Kong, China & $16.0-28.0$ & Li et al. (2020) \\
\hline C. malayensis (K-0972) & Tropical & Sulu Sea, Banggi Island, Malaysia & $25.0-30.0$ & Mohammad-Noor et al. (2013) \\
\hline C. monotis (CM300A) & $\begin{array}{l}\text { Subtropical- } \\
\text { temperate }\end{array}$ & Knight Key, Florida, USA & $21.0-35.0$ & Morton et al. (1992) \\
\hline C. monotis (CAWD39) & Subtropical & $\begin{array}{l}\text { Ninety Mile Beach, Northland, } \\
\text { New Zealand }\end{array}$ & $10.0-30.0$ & Rhodes et al. (2000) \\
\hline C. tropicalis (UTSHI1D5) & Tropical & $\begin{array}{l}\text { Heron Island Lagoon, QLD, } \\
\text { Australia }\end{array}$ & $<10.0-30.1$ & Larsson et al. (2019) \\
\hline C. tropicalis (UTSHI2D4) & Tropical & $\begin{array}{l}\text { Heron Island Lagoon, QLD, } \\
\text { Australia }\end{array}$ & $17.1-30.0$ & Larsson et al. (2019) \\
\hline C. tropicalis (UTSHI2D1) & Tropical & $\begin{array}{l}\text { Heron Island Lagoon, QLD, } \\
\text { Australia }\end{array}$ & $17.8-30.1$ & Larsson et al. (2019) \\
\hline C. tropicalis (K-1156) & Tropical & Sulu Sea, Banggi Island, Malaysia & $25.0-30.0$ & Mohammad-Noor et al. (2013) \\
\hline C. palmyrensis (UTSHI3C5) & Tropical & $\begin{array}{l}\text { Heron Island Lagoon, QLD, } \\
\text { Australia }\end{array}$ & $14.7-32.2$ & Larsson et al. (2019) \\
\hline Ostreopsis sp. 1 (HJ1-4) & Temperate & Jeju Island, Korea & $10.0-30.0$ & Kim and Seo (2019) \\
\hline Ostreopsis sp. 1 (s0716) & Temperate & Kochi Prefecture, Japan & $15.0-30.0$ & Tanimoto et al. (2013) \\
\hline O. cf. ovata & Temperate & East Sea and Jeju Island, Korea & $13.8-35.0$ & Sung (2015) \\
\hline O. cf. ovata (s0662) & Temperate & Tosa Bay, Kochi Prefecture, Japan & $17.5-30.0$ & Yamaguchi et al. (2012) \\
\hline $\begin{array}{l}\text { O. cf. ovata (IRTA-SMM-11-09, } \\
\text { IRTA-SMM-11-10) }\end{array}$ & $\begin{array}{l}\text { Subtropical- } \\
\text { tropical }\end{array}$ & $\begin{array}{l}\text { Catalonia, western Mediterra- } \\
\text { nean Sea }\end{array}$ & $19.0-28.0$ & Carnicer et al. (2016) \\
\hline O. heptagona (OH 100A) & $\begin{array}{l}\text { Subtropical- } \\
\text { temperate }\end{array}$ & Knight Key, Florida, USA & $16.0-31.0$ & Morton et al. (1992) \\
\hline O. siamensis (OS100A) & $\begin{array}{l}\text { Subtropical- } \\
\text { temperate }\end{array}$ & Knight Key, Florida, USA & $16.0-33.0$ & Morton et al. (1992) \\
\hline $\begin{array}{l}\text { O. siamensis (CAWD73, } \\
\text { CAWD74, CAWD75) }\end{array}$ & Subtropical & $\begin{array}{l}\text { Whatawhiwhi and Rangiputa, } \\
\text { Northland, New Zealand }\end{array}$ & $15.0-25.0$ & Rhodes et al. (2000) \\
\hline O. cf. ovata (T163) & Tropical & Koh Man, Rayong, Thailand & $20.0-32.5$ & Tawong et al. (2015) \\
\hline O. cf. ovata (TF5OS) & Tropical & Koh Wai, Trat, South China Sea & $20.0-32.5$ & Tawong et al. (2015) \\
\hline Ostreopsis sp. 6 (s0587) & Subtropical & Okinawa Prefecture, Japan & $17.5-30.0$ & Tanimoto et al. (2013) \\
\hline Ostreopsis sp. 6 (TF29OS) & Tropical & Koh Wai, Trat, Thailand & $20.0-32.5$ & Tawong et al. (2015) \\
\hline Ostreopsis sp. 7 (TB30OS) & Tropical & Khao Lak, Phang-Nga, Thailand & $20.0-30.0$ & Tawong et al. (2015) \\
\hline
\end{tabular}


Table 9. Water temperature $(\mathrm{T})$ range that allow the survival of benthic Gambierdiscus, Prorocentrum, and Amphidinium species living in the waters of Korea and other countries

\begin{tabular}{|c|c|c|c|c|}
\hline Species (strain) & Climate & Location & $\mathrm{T}\left({ }^{\circ} \mathrm{C}\right)$ & Reference \\
\hline Gambierdiscus jejuensis (GCJJ1) & Temperate & Jeju Island, Korea & $20.0-30.0$ & Jang et al. (2018) \\
\hline G. australes (S080911_1) & Temperate & Shikoku, Japan & $17.5-30.0$ & Yoshimatsu et al. (2014) \\
\hline G. carolinianus (NOAA 6) & Temperate & $\begin{array}{l}\text { Cape Fear, North Carolina, } \\
\text { Atlantic Ocean }\end{array}$ & $15.0-31.7$ & Kibler et al. (2012) \\
\hline G. scabrosus (KW070922_1) & Temperate & Shikoku, Japan & $17.5-30.0$ & Yoshimatsu et al. (2014) \\
\hline G. yasumotoi & Temperate & Jeju Island, Korea & $15.0-35.0$ & Sung (2015) \\
\hline $\begin{array}{l}\text { Gambierdiscus type } 2 \\
\text { (M080828_2) }\end{array}$ & Temperate & Shikoku, Japan & $17.5-30.0$ & Yoshimatsu et al. (2014) \\
\hline Gambierdiscus type 3 (WI11G) & Temperate & Honshu, Japan & $15.0-25.0$ & Yoshimatsu et al. (2014) \\
\hline G. toxicus (GT600) & Subtropical-temperate & Knight Key, Florida, USA & $19.5-34.0$ & Bomber et al. (1988) \\
\hline G. toxicus (GT600A) & Subtropical-temperate & Knight Key, Florida, USA & $19.0-35.0$ & Morton et al. (1992) \\
\hline G. belizeanus (CСMP 399) & Tropical & St. Barthelemy Island, Caribbean & $19.7-32.7$ & Kibler et al. (2012) \\
\hline G. caribaeus (NOAA 19) & Tropical & Carrie Bow Cay, Belize, Caribbean & $16.8-33.6$ & Kibler et al. (2012) \\
\hline G. caribaeus (TF9G) & Tropical & Koh Wai, Trat, Thailand & $20.0-35.0$ & Tawong et al. (2016) \\
\hline G. pacificus (CCMP 1650) & Tropical & $\begin{array}{l}\text { Moorea, Society Islands, Pacific } \\
\text { Ocean }\end{array}$ & $19.6-32.6$ & Kibler et al. (2012) \\
\hline G. ruetzleri (NOAA 8) & Tro & Carrie Bow Cay, Belize, Caribbean & 16. & Kibler et a \\
\hline $\begin{array}{l}\text { Gambierdiscus ribotype } 2 \\
\text { (CCMP 1655) }\end{array}$ & Tropical & Martinique, Caribbean & $19.8-31.1$ & Kibler et al. (2012) \\
\hline Prorocentrum lima & Temperate & Fleet Lagoon, Dors & $5.0-30.0$ & Aquino-Cruz et al. (2018) \\
\hline P. $\operatorname{lima}$ (PL 100A) & Subtropical-temperate & Knight Key, Florida, USA & $19.0-35.0$ & Morton et al. (1992) \\
\hline P. concavum (PC100A) & Subtropical-temperate & Knight Key, Florida, USA & $19.0-33.0$ & Morton et al. (1992) \\
\hline P. mexicanum (PM200A) & Subtropical-temperate & Knight Key, Florida, USA & $21.0-35.0$ & Morton et al. (1992) \\
\hline P. hoffmannianum (882a) & Tropical & $\begin{array}{l}\text { Little Lameshur Bay, Virgin Island, } \\
\text { USA }\end{array}$ & $21.0-36.0$ & Morton et al. (1994) \\
\hline Amphidinium carterae & Temperate & Jeju Island, Korea & $16.8-35.0$ & Sung (2015) \\
\hline A. operculatum & Temperate & Ulsan, East Sea, Korea & $17.1-35.0$ & Sung (2015) \\
\hline A. klebsii (AKI00A) & Subtropical-temperate & Knight Key, Florida, USA & $16.0-37.0$ & Morton et al. (1992) \\
\hline
\end{tabular}

Table 10. Macroalgal and seagrass species used for establishing sea forests in Korean waters

\begin{tabular}{|c|c|c|c|c|c|c|c|}
\hline Species & Edibility & $\begin{array}{l}\text { East } \\
\text { coast }\end{array}$ & $\begin{array}{l}\text { South } \\
\text { coast }\end{array}$ & $\begin{array}{l}\text { West } \\
\text { coast }\end{array}$ & $\begin{array}{l}\text { Jeju } \\
\text { Island }\end{array}$ & MA & Reference \\
\hline \multicolumn{8}{|l|}{ Phaeophyta } \\
\hline Eisenia bicyclis & Edible & + & & + & & NI & - \\
\hline Ecklonia cava & Edible & + & + & + & + & $33 / 53 / 69$ & Kim et al. (2011) \\
\hline Ecklonia cava subsp. stolonifera & Edible & + & + & + & & NI & - \\
\hline Sargassum horneri & Edible & & & + & & $24 / 1 / 57$ & Baek (2012b), Shah et al. $(2013 b)$ \\
\hline Sargassum macrocarpum & Edible & + & + & & & $30 / 0 / 49$ & Shah et al. $(2013 b)$ \\
\hline Sargassum fusiforme & Edible & & + & & & NI & - \\
\hline Sargassum fulvellum & Edible & + & + & + & + & NI & - \\
\hline Undaria pinnatifida & Edible & + & + & + & & $\mathrm{NI} / 10 / \mathrm{NI}$ & Baek $(2012 b)$ \\
\hline $\begin{array}{l}\text { Laminaria japonica } \\
\text { (= Saccharina japonica })\end{array}$ & Edible & + & + & + & & NI & - \\
\hline \multicolumn{8}{|l|}{ Rhodophyta } \\
\hline Gelidium amensii & Edible & & + & & & $21 / 426 / 688$ & Kim et al. (2011), Shah et al. (2013b) \\
\hline Agarophyton vermiculophyllum & Edible & & + & & & $14 / 0 / 52$ & Shah et al. $(2013 b)$ \\
\hline \multicolumn{8}{|l|}{ Chlorophyta } \\
\hline Codium fragile & Edible & & + & & & $0 / 0 / 21$ & Kim et al. (2011), Shah et al. (2013b) \\
\hline \multicolumn{8}{|l|}{ Seagrass } \\
\hline Zostera spp. & Inedible & & + & & & & - \\
\hline
\end{tabular}


lates, such as Gambierdiscus and Ostreopsis (Kim et al. 2011, Baek 2012b, Shah et al. 2013b) (Table 10). Thus, the consumption of these macroalgae harboring benthic dinoflagellates may cause illness in humans. This may be prevented by monitoring the abundance of benthic dinoflagellates in marine forests.

\section{CONCLUSION}

The epibenthic dinoflagellates Coolia spp., Gambierdiscus spp., Ostreopsis spp., Prorocentrum spp., and Amphidinium spp. have been found in the waters off Jeju Island and along the southern and eastern coast of Korea. The occurrence of some benthic dinoflagellates in the waters off Jeju Island may be affected by the rising seawater temperature around Korea. The presence of toxic benthic dinoflagellates may trigger Koreans to fear consuming raw seafood and edible macroalgae and eventually cause economic losses to the seafood industry. Therefore, it is important to investigate the distribution of toxic benthic dinoflagellates and continuously monitor their abundance continuously to prevent risks to human health. Molecular techniques may allow researchers to distinguish morphologically similar species and to monitor the abundance of toxic benthic dinoflagellates. All of these efforts will provide a better understanding of the epiphytic and benthic dinoflagellates in Korean waters.

\section{ACKNOWLEDGEMENTS}

This research was supported by the Useful Dinoflagellate program of Korea Institute of Marine Science and Technology Promotion (KIMST) funded by the Ministry of Oceans and Fisheries (MOF) and the National Research Foundation (NRF) funded by the Ministry of Science and ICT (NRF-2017R1E1A1A01074419) award to HJJ.

\section{CONFLICTS OF INTEREST}

The authors declare that they have no potential conflicts of interest.

\section{REFERENCES}

Accoroni, S., Percopo, I., Cerino, F., Romagnoli, T., Pichierri,
S., Perrone, C. \& Totti, C. 2015. Allelopathic interactions between the HAB dinoflagellate Ostreopsis cf. ovata and macroalgae. Harmful Algae 49:147-155.

Accoroni, S. \& Totti, C. 2016. The toxic benthic dinoflagellates of the genus Ostreopsis in temperate areas: a review. Adv. Oceanogr. Limnol. 7:1-15.

Aligizaki, K. \& Nikolaidis, G. 2006. The presence of the potentially toxic genera Ostreopsis and Coolia (Dinophyceae) in the North Aegean Sea, Greece. Harmful Algae 5:717-730.

Aquino-Cruz, A., Purdie, D. A. \& Morris, S. 2018. Effect of increasing sea water temperature on the growth and toxin production of the benthic dinoflagellate Prorocentrum lima. Hydrobiologia 813:103-122.

Baek, S. H. 2012a. First report for appearance and distribution patterns of the epiphytic dinoflagellates in the Korean peninsula. Korean J. Environ. Biol. 30:355-361.

Baek, S. H. 2012b. Occurrence of the toxic benthic dinoflagellate Gambierdiscus spp. in the uninhabited Baekdo Islands off southern coast and Seopsom Island in the Vicinity of Seogwipo, Jeju Province, Korea. Ocean Polar Res. 34:65-71.

Ben Gharbia, H., Kéfi-Daly Yahia, O., Cecchi, P., Masseret, E., Amzil, Z., Herve, F., Rovillon, G., Nouri, H., M'Rabet, C., Couet, D., Triki, H. Z. \& Laabir, M. 2017. New insights on the species-specific allelopathic interactions between macrophytes and marine HAB dinoflagellates. PLoS ONE 12:e0187963.

Besada, E. G., Loeblich, L. A. \& Loeblich, A. R. 3rd. 1982. Observations on tropical, benthic dinoflagellates from ciguatera-endemic areas: Coolia, Gambierdiscus, and Ostreopsis. Bull. Mar. Sci. 32:723-735.

Bomber, J. W., Guillard, R. R. L. \& Nelson, W. G. 1988. Role of temperature, salinity, and light in seasonality, growth, and toxicity of ciguatera-causing Gambierdiscus toxicus Adachi et Fukuyo (Dinophyceae). J. Exp. Mar. Biol. Ecol. 115:53-65.

Bomber, J. W., Rubio, M. G. \& Norris, D. R. 1989. Epiphytism of dinoflagellates associated with the disease ciguatera: substrate specificity and nutrition. Phycologia 28:360-368.

Carlson, R. D., Morey-Gaines, G., Tindall, D. R. \& Dickey, R. W. 1984. Ecology of toxic dinoflagellates from the Caribbean Sea: effects of macroalgal extracts on growth in culture. In Ragelis, E. P. (Ed.) Seafood Toxins. The American Chemical Society, Washington, D.C., pp. 271-287.

Carnicer, O., García-Altares, M., Andree, K. B., Tartaglione, L., Dell'Aversano, C., Ciminiello, P., de la Iglesia, P., Diogène, J. \& Fernández-Tejedor, M. 2016. Ostreopsis cf. ovata from western Mediterranean Sea: physiological 
responses under different temperature and salinity conditions. Harmful Algae 57:98-108.

Ciminiello, P., Dell'Aversano, C., Iacovo, E. D., Fattorusso, E., Forino, M., Tartaglione, L., Benedettini, G., Onorari, M., Serena, F., Battocchi, C., Casabianca, S. \& Penna, A. 2014. First finding of Ostreopsis cf. ovata toxins in marine aerosols. Environ. Sci. Technol. 48:3532-3540.

Cruz-Rivera, E. \& Villareal, T. A. 2006. Macroalgal palatability and the flux of ciguatera toxins through marine food webs. Harmful Algae 5:497-525.

Fraga, S., Penna, A., Bianconi, I., Paz, B. \& Zapata, M. 2008. Coolia canariensis sp. nov. (Dinophyceae), a new nontoxic epiphytic benthic dinflagellate from the Canary Islands. J. Phycol. 44:1060-1070.

Fukuyo, Y. 1981. Taxonomical study on benthic dinoflagellates collected in coral reefs. Bull. Jpn. Soc. Sci. Fish. 47:967-978.

Glibert, P. M., Burkholder, J. M. \& Kana, T. M. 2012. Recent insights about relationships between nutrient availability, forms, and stoichiometry, and the distribution, ecophysiology, and food web effects of pelagic and benthic Prorocentrum species. Harmful Algae 14:231-259.

Gómez, F., Qiu, D. \& Lin, S. 2017. The synonymy of the toxic dinoflagellates Prorocentrum mexicanum and $P$. rhathymum and the description of $P$. steidingerae sp. nov. (Prorocentrales, Dinophyceae). J. Eukaryot. Microbiol. 64:668-677.

Granéli, E., Vidyarathna, N. K., Funari, E., Cumaranatunga, P. R. T. \& Scenati, R. 2011. Can increases in temperature stimulate blooms of the toxic benthic dinoflagellate $O s$ treopsis ovata? Harmful Algae 10:165-172.

Hallegraeff, G. M. 2010. Ocean climate change, phytoplankton community responses, and harmful algal blooms: a formidable predictive challenge. J. Phycol. 46:220-235.

Han, I. -S. \& Lee, J. -S. 2020. Change the annual amplitude of sea surface temperature due to climate change in a recent decade around the Korean Peninsula. J. Korean Soc. Mar. Environ. Saf. 26:233-241.

Han, Y. B. 2010. Edible macroalgae 1. Component and bioactivity. Korea University Press, Seoul, 416 pp.

Holmes, M. J., Brust, A. \& Lewis, R. J. 2014. Dinoflagellate toxins: an overview. In Botana, L. M. (Ed.) Seafood and Freshwater Toxins: Pharmacology, Physiology, and Detection. 3rd ed. Marcel Dekker, New York, pp. 3-38.

Hwang, B. S., Yoon, E. Y., Jeong, E. J., Park, J., Kim, E. -H. \& Rho, J. -R. 2018. Determination of the absolute configuration of polyhydroxy compound ostreol B isolated from the dinoflagellate Ostreopsis cf. ovata. J. Org. Chem. 83:194-202.

Hwang, B. S., Yoon, E. Y., Kim, H. S., Yih, W., Park, J. Y., Jeong,
H. J. \& Rho, J. -R. 2013. Ostreol A: a new cytotoxic compound isolated from the epiphytic dinoflagellate Ostreopsis cf. ovata from the coastal waters of Jeju Island, Korea. Bioorg. Med. Chem. Lett. 23:3023-3027.

Hwang, E. K. \& Park, C. S. 2020. Seaweed cultivation and utilization of Korea. Algae 35:107-121.

Ibrahim, A. M. M. 2007. Review of the impact of harmful algae blooms and toxins on the world economy and human health. Egypt. J. Aquat. Res. 33:210-223.

Jang, S. H., Jeong, H. J. \& Yoo, Y. D. 2018. Gambierdiscus jejuensis sp. nov., an epiphytic dinoflagellate from the waters of Jeju Island, Korea, effect of temperature on the growth, and its global distribution. Harmful Algae 80:149-157

Jeong, H. J. 1999. The ecological roles of heterotrophic dinoflagellates in marine planktonic community. J. Eukaryot. Microbiol. 46:390-396.

Jeong, H. J., Kang, H. C., Lim, A. S., Jang, S. H., Lee, K., Lee, S. Y., Ok, J. H., You, J. H., Kim, J. H., Lee, K. H., Park, S. A., Eom, S. H., Yoo, Y. D. \& Kim, K. Y. 2021 $a$. Feeding diverse prey as an excellent strategy of mixotrophic dinoflagellates for global dominance. Sci. Adv. 7:eabe4214.

Jeong, H. J., Lim, A. S., Franks, P. J. S., Lee, K. H., Kim, J. H., Kang, N. S., Lee, M. J., Jang, S. H., Lee, S. Y., Yoon, E. Y., Park, J. Y., Yoo, Y. D., Seong, K. A., Kwon, J. E. \& Jang, T. Y. 2015. A hierarchy of conceptual models of red-tide generation: nutrition, behavior, and biological interactions. Harmful Algae 47:97-115.

Jeong, H. J., Lim, A. S., Jang, S. H., Yih, W. H., Kang, N. S., Lee, S. Y., Yoo, Y. D. \& Kim, H. S. 2012a. First report of the epiphytic dinoflagellate Gambierdiscus caribaeus in the temperate waters off Jeju Island, Korea: morphology and molecular characterization. J. Eukaryot. Microbiol. 59:637-650.

Jeong, H. J., Ok, J. H., Lim, A. S., Kwon, J. E., Kim, S. J. \& Lee, S. Y. 2016. Mixotrophy in the phototrophic dinoflagellate Takayama helix (family Kareniaceae): predator of diverse toxic and harmful dinoflagellates. Harmful Algae 60:92-106.

Jeong, H. J., Yih, W., Kang, N. S., Lee, S. Y., Yoon, E. Y., Yoo, Y. D., Kim, H. S. \& Kim, J. H. 2012b. First report of the epiphytic benthic dinoflagellates Coolia canariensis and Coolia malayensis in the waters off Jeju Island, Korea: morphology and rDNA sequences. J. Eukaryot. Microbiol. 59:114-133.

Jeong, H. J., Yoo, Y. D., Kim, J. S., Seong, K. A., Kang, N. S. \& Kim, T. H. 2010. Growth, feeding, and ecological roles of the mixotrophic and heterotrophic dinoflagellates in marine planktonic food webs. Ocean Sci. J. 45:65-91.

Jeong, H. J., Yoo, Y. D., Lee, K., Kang, H. C., Kim, J. S. \& Kim, K. 
Y. 2021b. Annual carbon retention of a marine-plankton community in the eutrophic Masan Bay, based on daily measurements. Mar. Biol. 168:69.

Kang, N. S., Jeong, H. J., Lee, S. Y., Lim, A. S., Lee, M. J., Kim, H. S. \& Yih, W. 2013. Morphology and molecular characterization of the epiphytic benthic dinoflagellate $O s$ treopsis cf. ovata in the temperate waters off Jeju Island, Korea. Harmful Algae 27:98-112.

Kang, Y. Q. 2000. Warming trend of coastal waters of Korea during recent 60 years (1936-1995). Fish. Aquat. Sci. 3:173-179.

Karafas, S., Teng, S. T., Leaw, C. P. \& Alves-de-Souza, C. 2017. An evaluation of the genus Amphidinium (Dinophyceae) combining evidence from morphology, phylogenetics, and toxin production, with the introduction of six novel species. Harmful Algae 68:128-151.

Kibler, S. R., Litaker, R. W., Holland, W. C., Vandersea, M. W. \& Tester, P. A. 2012. Growth of eight Gambierdiscus (Dinophyceae) species: effects of temperature, salinity and irradiance. Harmful Algae 19:1-14.

Kim, H. S., Yih, W., Kim, J. H., Myung, G. \& Jeong, H. J. 2011. Abundance of epiphytic dinofalgellates from coastal waters off Jeju Island, Korea during Autumn 2009. Ocean Sci. J. 46:205-209.

Kim, S. \& Seo, H. 2019. Distribution and molecular phylogeny of the toxic benthic dinoflagellate Ostreopsis sp. in the coastal waters off Jeju Island, Korea. The Sea 24:236-248.

Kohli, G. S., Murray, S. A., Neilan, B. A., Rhodes, L. L., Harwood, D. T., Smith, K. F., Meyer, L., Capper, A., Brett, S. \& Hallegraeff, G. M. 2014. High abundance of the potentially maitotoxic dinoflagellate Gambierdiscus carpenteri in temperate waters of New South Wales, Australia. Harmful Algae 39:134-145.

Korea Fisheries Resources Agency. 2020. Marine forests white paper, Korea. Korea Fisheries Resources Agency, Busan, $368 \mathrm{pp}$.

Kwak, M. -T., Seo, G. -H., Cho, Y. -K., Kim, B. -G., You, S. -H. \& Seo, J. -W. 2015. Long-term comparison of satellite and in-situ sea surface temperatures around the Korean Peninsula. Ocean Sci. J. 50:109-117.

Kwon, J. E., Jeong, H. J., Kim, S. J., Jang, S. H., Lee, K. H. \& Seong, K. A. 2017. Newly discovered role of the heterotrophic nanoflagellate Katablepharis japonica, a predator of toxic or harmful dinoflagellates and raphidophytes. Harmful Algae 68:224-239.

Larsson, M. E., Smith, K. F. \& Doblin, M. A. 2019. First description of the environmental niche of the epibenthic dinoflagellate species Coolia palmyrensis, C. malayensis, and C. tropicalis (Dinophyceae) from Eastern Australia. J. Phycol. 55:565-577.
Laza-Martinez, A., Orive, E. \& Miguel, I. 2011. Morphological and genetic characterization of benthic dinoflagellates of the genera Coolia, Ostreopsis and Prorocentrum from the south-eastern Bay of Biscay. Eur. J. Phycol. 46:45-65.

Leaw, C. -P., Lim, P. -T., Cheng, K. -W., Ng, B. -K. \& Usup, G. 2010. Morphology and molecular characterization of new species of thecate benthic dinoflagellate, Coolia malayensis sp. nov. (Dinophyceae). J. Phycol. 46:162-171.

Leaw, C. P., Tan, T. H., Lim, H. C., Teng, S. T., Yong, H. L., Smith, K. F., Rhodes, L., Wolf, M., Holland, W. C., Vandersea, M. W., Litaker, R. W., Tester, P. A., Gu, H., Usup, G. \& Lim, P. T. 2016. New scenario for speciation in the benthic dinoflagellate genus Coolia (Dinophyceae). Harmful Algae 55:137-149.

Lee, B. \& Park, M. G. 2018. Genetic analyses of the $r b c \mathrm{~L}$ and psaA genes from single cells demonstrate a Rhodophyte origin of the prey in the toxic benthic dinoflagellate $\mathrm{Os}$ treopsis. Front. Mar. Sci. 5:217.

Lee, B. \& Park, M. G. 2020. Distribution and genetic diversity of the toxic benthic dinoflagellate genus Ostreopsis in Korea. Harmful Algae 96:101820.

Lee, K. H., Jeong, H. J., Park, K., Kang, N. S., Yoo, Y. D., Lee, M. J., Lee, J. -W., Lee, S., Kim, T., Kim, H. S. \& Noh, J. H. 2013. Morphology and molecular characterization of the epiphytic dinoflagellate Amphidinium massartii, isolated from the temperate waters off Jeju Island, Korea. Algae 28:213-231.

Lee, K. -W., Kang, J. -H., Baek, S. -H., Choi, Y. -U., Lee, D. -W. \& Park, H. -S. 2014. Toxicity of the dinoflagellate Gambierdiscus sp. toward the marine copepod Tigriopus japonicus. Harmful Algae 37:62-67.

Lee, L. K., Lim, Z. F., Gu, H., Chan, L. L., Litaker, R. W., Tester, P. A., Leaw, C. P. \& Lim, P. T. 2020. Effects of substratum and depth on benthic harmful dinoflagellate assemblages. Sci. Rep. 10:11251.

Lee, S., Yang, A. R., Yoo, Y. D., Jeong, E. J. \& Rho, J. -R. 2019. Relative configurational assignment of 4-hydroxyprorocentrolide and prorocentrolide $\mathrm{C}$ isolated from a benthic Dinoflagellate (Prorocentrum lima). J. Nat. Prod. 82:1034-1039.

Lessard, E. J. 1991. The trophic role of heterotrophic dinoflagellates in diverse marine environments. Mar. Microb. Food Web 5:49-58.

Li, X., Yan, M., Gu, J., Lam, V. T. T., Wai, T. -C., Baker, D. M. Thompson, P. D., Yiu, S. K. F., Lam, P. K. S. \& Leung, P. T. Y. 2020. The effect of temperature on physiology, toxicity and toxin content of the benthic dinoflagellate Coolia malayensis from a seasonal tropical region. Water Res. 185:116264. 
Lie, H. -J. \& Cho, C. -H. 2016. Seasonal circulation patterns of the Yellow and East China Seas derived from satellitetracked drifter trajectories and hydrographic observations. Prog. Oceanogr. 146:121-141.

Lim, A. S., Jeong, H. J., Jang, T. Y., Kang, N. S., Lee, S. Y., Yoo, Y. D. \& Kim, H. S. 2013. Morphology and molecular characterization of the epiphytic dinoflagellate Prorocentrum cf. rhathymum in temperate waters off Jeju Island, Korea. Ocean Sci. J. 48:1-17.

Lim, A. S., Jeong, H. J., Ok, J. H. \& Kim, S. J. 2018. Feeding by the harmful phototrophic dinoflagellate Takayama tasmanica (Family Kareniaceae). Harmful Algae 74:19-29.

Litaker, R. W., Vandersea, M. W., Faust, M. A., Kibler, S. R., Chinain, M., Holmes, M. J., Holland, W. C. \& Tester, P. A. 2009. Taxonomy of Gambierdiscus including four new species, Gambierdiscus caribaeus, Gambierdiscus carolinianus, Gambierdiscus carpenteri, and Gambierdiscus ruetzleri (Gonyaulacales, Dinophyceae). Phycologia 48:344-390.

Litaker, R. W., Vandersea, M. W., Faust, M. A., Kibler, S. R., Nau, A. W., Holland, W. C. Chinain, M., Holmes, M. J. \& Tester, P. A. 2010. Global distribution of ciguatera causing dinoflagellates in the genus Gambierdiscus. Toxicon 56:711-730.

Loeblich, A. R., Sherley, J. L. \& Schmidt, R. J. 1979. The correct position of flagellar insertion in Prorocentrum and description of Prorocentrum rhathymum sp. nov. (Phyrrhophyta). J. Plankton Res. 1:113-120.

Mangialajo, L., Ganzin, N., Accoroni, S., Asnaghi, V., Blanfuné, A., Cabrini, M., Cattaneo-Vietti, R., Chavanon, F., Chiantore, M., Cohu, S., Costa, E., Fornasaro, D., Grossel, H., Marco-Miralles, F., Masó, M., Reñé, A., Rossi, A. M., Sala, M. M., Thibaut, T., Totti, C., Vila, M. \& Lemée, R. 2011. Trends in Ostreopsis proliferation along the Northern Mediterranean coasts. Toxicon 57:408-420.

Ministry of Oceans and Fisheries. 2020. Annual statistical report for oceans and fishery in Korea. Ministry of Oceans and Fisheries, Sejong, $502 \mathrm{pp}$.

Mohammad-Noor, N., Moestrup, Ø., Lundholm, N., Fraga, S., Adam, A., Holmes, M. J. \& Saleh, E. 2013. Autecology and phylogeny of Coolia tropicalis and Coolia malayensis (Dinophyceae), with emphasis on taxonomy of $C$. tropicalis based on light microscopy, scanning electron microscopy and LSU rDNA. J. Phycol. 49:536-545.

Morton, S. L., Bomber, J. W. \& Tindall, P. M. 1994. Environmental effects on the production of okadaic acid from Prorocentrum hoffmannianum Faust I. temperature, light, and salinity. J. Exp. Mar. Biol. Ecol. 178:67-77.

Morton, S. L., Norris, D. R. \& Bomer, J. W. 1992. Effect of temperature, salinity and light intensity on the growth and seasonality of toxic dinofalgellates associated with ciguatera. J. Exp. Mar. Biol. Ecol. 157:79-90.

Murray, S. A., Garby, T., Hoppenrath, M. \& Neilan, B. A. 2012. Genetic diversity, morphological uniformity and polyketide production in dinoflagellates (Amphidinium, Dinoflagellata). PLoS ONE 7:e38253.

Mustapa, N. I., Yong, H. L., Lee, L. K., Lim, Z. F., Lim, H. C., Teng, S. T., Luo, Z., Gu, H., Leaw, C. P. \& Lim, P. T. 2019. Growth and epiphytic behavior of three Gambierdiscus species (Dinophyceae) associated with various macroalgal substrates. Harmful Algae 89:101671.

Nishimura, T., Uchida, H., Noguchi, R., Oikawa, H., Suzuki, T., Funaki, H., Ihara, C., Hagino, K., Arimitsu, S., Tanii, Y., Abe, S., Hashimoto, K., Mimura, K., Tanaka, K., Yanagida, I. \& Adachi, M. 2020. Abundance of the benthic dinoflagellate Prorocentrum and the diversity, distribution, and diarrhetic shellfish toxin production of Prorocentrum lima complex and P. caipirignum in Japan. Harmful Algae 96:101687.

Ok, J. H., Jeong, H. J., Lim, A. S., Lee, S. Y. \& Kim, S. J. 2018. Feeding by the heterotrophic nanoflagellate Katablepharis remigera on algal prey and its nationwide distribution in Korea. Harmful Algae 74:30-45.

Park, J., Hwang, J., Hyung, J. -H. \& Yoon, E. Y. 2020. Temporal and spatial distribution of the toxic epiphytic dinoflagellate Ostreopsis cf. ovata in the coastal waters off Jeju Island, Korea. Sustainability 12:5864.

Parsons, M. L., Aligizaki, K., Bottein, M. -Y. D., Fraga, S., Morton, S. L., Penna, A. \& Rhodes, L. 2012. Gambierdiscus and Ostreopsis: reassessment of the state of knowledge of their taxonomy, geography, ecophysiology, and toxicology. Harmful Algae 14:107-129.

Parsons, M. L. \& Preskitt, L. B. 2007. A survey of epiphytic dinoflagellates from the coastal waters of the island of Hawai'i. Harmful Algae 6:658-669.

Pavaux, A. -S., Berdalet, E. \& Lemée, R. 2020. Chemical ecology of the benthic dinoflagellate genus Ostreopsis: review of progress and future directions. Front. Mar. Sci. 7:498.

Pezzolesi, L., Guerrini, F., Ciminiello, P., Dell'Aversano, C., Iacovo, E. D., Fattorusso, E., Forino, M., Tartaglione, L. \& Pistocchi, R. 2012. Influence of temperature and salinity on Ostreopsis cf. ovata growth and evaluation of toxin content through HR LC-MS and biological assays. Water Res. 46:82-92.

Rhodes, L. 2011. World-wide occurrence of the toxic dinoflagellate genus Ostreopsis Schmidt. Toxicon 57:400-407.

Rhodes, L., Adamson, J., Suzuki, T., Briggs, L. \& Garthwaite, I. 2000. Toxic marine epiphytic dinoflagellates, Ostreopsis siamensis and Coolia monotis (Dinophyceae), in New Zealand. N. Z. J. Mar. Freshw. Res. 34:371-383. 
Rhodes, L. \& Thomas, A. E. 1997. Coolia monotis (Dinophyceae): a toxic epiphytic microalgal species found in New Zealand. N. Z. J. Mar. Freshw. Res. 31:139-141.

Sato, S., Nishimura, T., Uehara, K., Sakanari, H., Tawong, W., Hariganeya, N., Smith, K., Rhodes, L., Yasumoto, T., Taira, Y., Suda, S., Yamaguchi, H. \& Adachi, M. 2011. Phylogeography of Ostreopsis along west Pacific coast, with special reference to a novel clade from Japan. PLoS ONE 6:e27983.

Schmidt, J. 1901. Flora of Koh Chang. Contributions to the knowledge of the vegetation in the Gulf of Siam. Peridiniales. Bot. Tidsskr. 24:212-221.

Selina, M. S., Morozova, T. V., Vyshkvartsev, D. I. \& Orlova, T. Y. 2014. Seasonal dynamics and spatial distribution of epiphytic dinoflagellates in Peter the Great Bay (Sea of Japan) with special emphasis on Ostreopsis species. Harmful Algae 32:1-10.

Shah, M. M. R., An, S. -J. \& Lee, J. -B. 2013a. Presence of benthic dinoflagellates around coastal waters of Jeju Island including newly recorded species. J. Ecol. Environ. 36:347-370.

Shah, M. M. R., An, S. -J. \& Lee, J. -B. 2013b. Seasonal abundance of epiphytic dinoflagellates around coastal waters of Jeju Island, Korea. J. Mar. Sci. Technol. 21:156-165.

Shah, M. M. R., An, S. -J. \& Lee, J. -B. 2014a. Occurrence of sand-dwelling and epiphytic dinoflagellates including potentially toxic species along the coast of Jeju Island, Korea. J. Fish. Aquat. Sci. 9:141-156.

Shah, M. M. R., Samarakoon, K. W., Ko, J. -Y., Lakmal, H. H. C., Lee, J. -H., An, S. -J., Jeon, Y. -J. \& Lee, J. -B. 2014b. Potentiality of benthic dinoflagellate cultures and screening of their bioactivities in Jeju Island, Korea. Afr. J. Biotechnol. 13:792-805.

Shears, N. T. \& Ross, P. M. 2009. Blooms of benthic dinoflagellates of the genus Ostreopsis: an increasing and ecologically important phenomenon on temperate reefs in New Zealand and worldwide. Harmful Algae 8:916-925.

Sherr, E. B. \& Sherr, B. F. 2007. Heterotrophic dinoflagellates: a significant component of microzooplankton biomass and major grazers of diatoms in the sea. Mar. Ecol. Prog. Ser. 352:187-197.

Sung, J. W. 2015. Phylogenetic position, morphological and physiological characterization of five benthic epiphytic dinoflagellates isolated from Korean coastal waters. M.S. thesis, Hanyang University, Seoul, Korea, 69 pp.

Tanimoto, Y., Yamaguchi, H., Yoshimatsu, T., Sato, S. \& Adachi, M. 2013. Effects of temperature, salinity and their interaction on growth of toxic Ostreopsis sp. 1 and Ostreopsis sp. 6 (Dinophyceae) isolated from Japanese coastal waters. Fish. Sci. 79:285-291.
Tawong, W., Yoshimatsu, T., Yamaguchi, H. \& Adachi, M. 2015. Effects of temperature, salinity and their interaction on growth of benthic dinoflagellates Ostreopsis spp. from Thailand. Harmful Algae 44:37-45.

Tawong, W., Yoshimatsu, T., Yamaguchi, H. \& Adachi, M. 2016. Temperature and salinity effects and toxicity of Gambierdiscus caribaeus (Dinophyceae) from Thailand. Phycologia 55:274-278.

Terrado, R., Vincent, W. F. \& Lovejoy, C. 2009. Mesopelagic protists: diversity and succession in a coastal Arctic ecosystem. Aquat. Microb. Ecol. 56:25-39.

Tester, P. A., Litaker, R. W. \& Berdalet, E. 2020. Climate change and harmful benthic microalgae. Harmful Algae 91:101655.

Tichadou, L., Glaizal, M., Armengaud, A., Grossel, H., Lemée, R., Kantin, R., Lasalle, J. -L., Drouet, G., Rambaud, L., Malfait, P. \& De Haro, L. 2010. Health impact of unicellular algae of the Ostreopsis genus blooms in the Mediterranean Sea: experience of the French Mediterranean coast surveillance network from 2006 to 2009. Clin. Toxicol. 48:839-844.

Tindall, D. R. \& Morton, S. L. 1998. Community dynamics and physiology of epiphytic/benthic dinoflagellates associated with ciguatera. In Anderson, D. M., Cembella, A. D. \& Hallegraeff, G. M. (Eds.) Physiological Ecology of Harmful Algal Blooms. NATO ASI Series. Springer, Heidelberg, pp. 293-313.

Tubaro, A., Durando, P., Del Favero, G., Ansaldi, F., Icardi, G., Deeds, J. R. \& Sosa, S. 2011. Case definitions for human poisonings postulated to palytoxins exposure. Toxicon 57:478-495.

Vila, M., Gracés, E. \& Masó, M. 2001. Potentially toxic epiphytic dinoflagellate assemblages on macroalgae in the NW Mediterranean. Aquat. Microb. Ecol. 26:51-60.

Yamaguchi, H., Yoshimatsu, T., Tanimoto, Y., Sato, S., Nishimura, T., Uehara, K. \& Adachi, M. 2012. Effects of temperature, salinity and their interaction on growth of the benthic dinoflagellate Ostreopsis cf. ovata (Dinophyceae) from Japanese coastal waters. Phycol. Res. 60:297-304.

Yang, A. R., Lee, S., Yoo, Y. D., Kim, H. S., Jeong, E. J. \& Rho, J. -R. 2017. Limaol: a polyketide from the benthic marine dinoflagellate Prorocentrum lima. J. Nat. Prod. 80:1688-1692.

Yong, H. L., Mustapa, N. I., Lee, L. K., Lim, Z. F., Tan, T. H., Usup, G., Gu, H., Litaker, R. W., Tester, P. A., Lim, P. T. \& Leaw, C. P. 2018. Habitat complexity affects benthic harmful dinoflagellate assemblages in the fringing reef of Rawa Island, Malaysia. Harmful Algae 78:56-68.

Yoo, Y. D., Jeong, H. J., Lee, S. Y., Yoon, E. Y., Kang, N. S., Lim, 
A. S., Lee, K. H., Jang, S. H., Park, J. Y. \& Kim, H. S. 2015. Feeding by heterotrophic protists on the toxic dinoflagellate Ostreopsis cf. ovata. Harmful Algae 49:1-9.

Yoshimatsu, T., Yamaguchi, H., Iwamoto, H., Nishimura, T. \& Adachi, M. 2014. Effects of temperature, salinity and their interaction on growth of Japanese Gambierdiscus spp. (Dinophyceae). Harmful Algae 35:29-37.

You, J. H., Jeong, H. J., Kang, H. C., Ok, J. H., Park, S. A. \&
Lim, A. S. 2020. Feeding by common heterotrophic protist predators on seven Prorocentrum species. Algae 35:61-78.

Zingone, A., Siano, R., D’Alelio, D. \& Sarno, D. 2006. Potentially toxic and harmful microalgae from coastal waters of the Campania region (Tyrrhenian Sea, Mediterranean Sea). Harmful Algae 5:321-337. 